\title{
Picking Up Where the TMDL Leaves Off: Using the Partnership Wild and Scenic River Framework for Collaborative River Restoration
}

\author{
Alan R. Hunt ${ }^{1, *(\mathbb{D}) \text {, Meiyin Wu }}{ }^{2,3}$, Tsung-Ta David Hsu ${ }^{2,3}$, Nancy Roberts-Lawler ${ }^{1}$, Jessica Miller ${ }^{4}(\mathbb{D}$, \\ Alessandra Rossi ${ }^{2,4}$ (D) and Lee H. Lee ${ }^{3}$ \\ 1 Musconetcong Watershed Association, Asbury, NJ 08802, USA; nancy@musconetcong.org \\ 2 New Jersey Center for Water Science and Technology, Montclair State University, Montclair, NJ 07043, USA; \\ wum@montclair.edu (M.W.); hsut@mail.montclair.edu (T.-T.D.H.); rossia@montclair.edu (A.R.) \\ 3 Department of Biology, Montclair State University, Montclair, NJ 07043, USA; leel@montclair.edu \\ 4 Department of Earth and Environmental Studies, Montclair State University, Montclair, NJ 07043, USA; \\ miller1j@mail.montclair.edu \\ * Correspondence: alan@musconetcong.org; Tel.:+1-(908)-537-7060
}

check for updates

Citation: Hunt, A.R.; Wu, M.; Hsu, T.-T.D.; Roberts-Lawler, N.; Miller, J.; Rossi, A.; Lee, L.H. Picking Up Where the TMDL Leaves Off: Using the Partnership Wild and Scenic River Framework for Collaborative River Restoration. Sustainability 2021, 13, 1878. https://doi.org/10.3390/ su13041878

Academic Editor: Pekka Jokinen Received: 30 December 2020

Accepted: 2 February 2021

Published: 9 February 2021

Publisher's Note: MDPI stays neutral with regard to jurisdictional claims in published maps and institutional affiliations.

Copyright: (c) 2021 by the authors. Licensee MDPI, Basel, Switzerland. This article is an open access article distributed under the terms and conditions of the Creative Commons Attribution (CC BY) license (https:/ / creativecommons.org/licenses/by/ $4.0 /)$.

\begin{abstract}
The National Wild and Scenic Rivers Act protects less than $\frac{1}{4}$ of a percent of the United States' river miles, focusing on free-flowing rivers of good water quality with outstandingly remarkable values for recreation, scenery, and other unique river attributes. It predates the enactment of the Clean Water Act, yet includes a clear anti-degradation principle, that pollution should be reduced and eliminated on designated rivers, in cooperation with the federal Environmental Protection Agency and state pollution control agencies. However, the federal Clean Water Act lacks a clear management framework for implementing restoration activities to reduce non-point source pollution, of which bacterial contamination impacts nearly $40 \%$ of the Wild and Scenic Rivers. A case study of the Musconetcong River, in rural mountainous New Jersey, indicates that the Wild and Scenic Rivers Act can be utilized to mobilize and align non-governmental, governmental, philanthropic, and private land-owner resources for restoring river water quality. For example, coordinated restoration efforts on one tributary reduced bacterial contamination by $95 \%$, surpassing the TMDL goal of a $93 \%$ reduction. Stakeholder interviews and focus groups indicated widespread knowledge and motivation to improve water quality, but resource constraints limited the scale and scope of restoration efforts. The authors postulate that the Partnership framework, enabled in the Wild and Scenic Rivers Act, facilitated neo-endogenous rural development through improving water quality for recreational usage, whereby bottom-up restoration activities were catalyzed via federal designation and resource provision. However, further efforts to address water quality via voluntary participatory frameworks were ultimately limited by the public sector's inadequate funding and inaction with regard to water and wildlife resources in the public trust.
\end{abstract}

Keywords: community-based natural resource management; participatory resource management; water quality; Total Maximum Daily Load (TMDL); Microbial Source Tracking (MST); Wild and Scenic River; neo-endogenous rural development; river management

\section{Introduction}

The national Wild and Scenic Rivers Act (WSRA) protects less than $\frac{1}{4}$ of one percent $(0.025 \%)$ of the United States' river miles, focusing on free-flowing rivers of good water quality with outstandingly remarkable values for recreation, scenery, and other unique river attributes. Good water quality is a condition for designation, and once designated, the responsible federal agency is charged to work with the Environmental Protection Agency (EPA) and the state pollution control agency "for the purpose of eliminating or diminishing the pollution of waters of the river" through Section 12(c) of the WSRA [1]. However, there 
is a bifurcation in approaches to manage water quality on Wild and Scenic Rivers (WSRs), because WSRA legislation originated from Congressional committees, which did not have jurisdiction over water quality [2], and the EPA and the states utilize mechanisms provided in the Clean Water Act (CWA).

WSR designation often is a factor in determining designating use, surface water quality standards, anti-degradation standards, discharge permitting, and local land use decisions. For example, the EPA indicates that WSR segments can be designated by states as Outstanding National Resource Waters (ONRW), and receive the highest level of antidegradation protection, based upon recreational significance of designated rivers [3-5]. At least half of the fifty states have adopted an ONRW anti-degradation standard. While the ONRW designation applies to point source discharges, non-point source pollution affects a significant share of WSRs. Non-point source pollution impacts about $44 \%$ of designated WSRs and nearly one third have not been assessed for water quality [5].

Federal agencies managing WSRs typically manage land use along river corridors to prevent water quality degradation, collaborate with state agencies, or utilize the judicial system to manage water quality, as they lack jurisdiction. The Interagency Wild and Scenic River Council reports that of the assessed WSRs and assessed rivers nationwide, $71 \%$ were found to be impaired compared to $53 \%$ impaired nationwide [6]. The main causes of these impairments are temperature, mercury, metals, sediment, PCBs, and pathogens [6]. Many of these impairments have the potential to impact recreational usages, such as fish consumption, primary contact recreation, and secondary contact recreation, and can complicate river management, which includes the promotion of recreational usage.

While the WSRA statute provides a mandate to reduce and eliminate pollution, there is distance between that goal and rivers' water quality conditions. Additionally, river managers face a potentially conflicting mandate of encouraging recreational usage on impaired waters. For example, of the 840 miles of WSRs impaired by pathogens (i.e., bacteria), the Musconetcong River's WSR segments represent 3\% of the pathogen-impaired river miles in the National Wild and Scenic River System [6]. The jurisdictional and institutional divisions between water quality regulators and river managers results in conflicting mandates and underlying weakness in the durable protection of WSRs.

The Partnership Wild and Scenic River (PWSR) model offers an alternative approach to managing river water quality. This approach developed in response to public resistance against federal land acquisition along WSR corridors in the American East. Unlike the American West, where much land is in public ownership and many WSRs have been designated, the East is dominated by private land ownership. In the PWSR model, there is no federal land acquisition. By selecting a local cooperating partner, and providing funding and technical assistance, the National Park Service (NPS) enables a third party to form partnerships necessary to implement the required Comprehensive River Management Plan. While no federal authority is delegated to the cooperating partner, it can conduct the public advocacy necessary to achieve WSRA goals, including inter-agency (lateral) and multi-level (hierarchical) collaboration.

This case of the Musconetcong River indicates how WSR designation can motivate and sustain water quality protection, enable restoration, foster multi-sector partnerships, promote inter-agency coordination, and achieve water quality improvements in alignment with WSRA goals, including the reduction and elimination of pollution. Events supporting these outcomes span more than 25 years, and are indicated through interdisciplinary, mixed methods research by:

- Establishing the political, regulatory, and management context of the Clean Water Act and Wild and Scenic Rivers Act.

- Developing a single case study to describe organizational capacity development, utilizing primary source documents and stakeholder interviews.

- Summarizing water quality changes and improvements.

- Locating the case study within theories of economic development in rural areas. 


\subsection{Challenges of Voluntary Conservation Approaches to Address Water Quality Impairments}

The CWA regulates non-point source pollution through a process of water quality monitoring, assessments for impairment (including classification on the 303(d) impaired waters list), and the establishment of Total Maximum Daily Loads (TMDLs), which include pollutant load reduction targets for probable sources. With no "end of pipe" to regulate, reducing pollutants listed in a TMDL has been extremely difficult, given the cumulative impact of pollution from diffuse sources $[7,8]$. The fragmentation of legal authority to manage non-point pollution stymied effective approaches for its management [8-10].

Voluntary, participatory, and collaborative multi-sector partnerships were proposed to address failures in effective environmental regulation. For example, in the Clinton Administration's Sustainable Development Council (1993-1999) Sustainable America report, these approaches were favored in part because "local stakeholders for the various interests involved in a particular natural resources issue may be able to contribute to more informed and reasoned choices—collectively—for resolving issues" [11] (p. 115). Following the Council's report was the 1998 Clean Water Action Plan, from the EPA and U.S. Department of Agriculture (USDA), which aimed to launch a "new cooperative approach to watershed protection in which state, tribal, federal, and local governments, and the public first identify the watersheds with the most critical water quality problems and then work together to focus resources and implement effective strategies to solve these problems" [12] (cover letter). The Clean Water Action Plan proposed the formation of "community-based watershed partnerships," including homeowners, farmers and ranchers, and community leaders, which were to be supported by small "watershed assistance grants" [12] (pp. 82-83). Public agencies were to prioritize the allocation of limited resources, potentially with the input of these local, multi-sector partnerships.

Accordingly, in the late 1990s and 2000s, voluntary environmental approaches became a dominant strategy in natural resource management [9]. The highest profile effort to address the national-local coordination gap is the Chesapeake Bay Program, which seeks to engage the agencies and private-sector interests in six states and the District of Columbia in addressing the Bay's TMDL goals $[8,13]$. This effort, as well as several others, set out to coordinate the actions of state agencies, local governments, landowners, and local stakeholder organizations, through voluntary conservation incentives and water quality management.

Despite the Clinton Administration's proposed collaborative partnership approach, federal resources remained balkanized, with varying programmatic and eligibility requirements across federal and state agencies [9]. The high coordination costs of marshalling resources across agencies and levels of government to address specific water quality needs was quickly, and widely, acknowledged as a gap to achieve the goal of non-point pollution reduction envisioned within the CWA [9,13]. Layzer and Rinfret (2019) concluded "the experience of the bay program provided support for the view that non-regulatory approaches are insufficient to bring about fundamental changes in industry, municipal, or household behavior [8] (p. 122)".

Efforts such as the Bay Program were hampered by the TMDL's overreliance on the voluntary approach without clearly defined and measurable outcomes [12]. In 1997, EPA was sued due to inaction on the development of TMDLs; the Chesapeake Bay Foundation was one of a number of complainants $[7,14]$. The conclusion of this lawsuit, Sierra Club et al. v. EPA led to the EPA forming new Memorandums of Agreements with the states to establish TMDLs for impaired waters [15]. Later, the Government Accountability Office (GAO) concluded that, after reviewing TMDL implementation for over 40 years, "Without changes to the program's voluntary approach to implement projects in waters impaired by nonpoint source pollution, the [Clean Water] act's goals are likely to remain unfulfilled" [16] (p. 63).

While the Clinton Administration attempted, through Executive leadership, to establish collaborative watershed management, the underlying statues and funding (under the control of Congress) had not changed. Without the successful engagement of Congress to 
institutionalize the Administration's clean water funding priorities, President Clinton's priorities for collaborative watershed management were short-lived.

The incoming Bush Administration, in 2001, had different water quality priorities for EPA, focusing on water quality trading. The Administration narrowed the application of cooperative watershed management to 16 projects centered on U.S. Forests [17]. Changing Presidential priorities to focus collaborative watershed management approaches to federal lands also undermined the practical expansion of collaborative watershed management.

In New Jersey, these shifting federal priorities affected on the ground collaborative watershed management efforts. During 1998-2000, New Jersey implemented a watershed management program with funding support through the CWA, as implemented by the Clinton Administration. This state-led effort intersected with the Musconetcong River's WSR designation effort [18] (p. 5). However, the State's effort was short-lived when federal funding ended after 2000. Without federal funding, the N.J. Department of Environmental Protection (NJDEP), along with other states' environmental agencies, returned to focus on implementing the legal and regulatory changes necessitated by Sierra Club et al. v. EPA [14]. Accordingly, NJDEP developed a TMDL for the Musconetcong's bacterial contamination in 2003 [19].

However, the Musconetcong's WSR designation efforts continued on, supported by over a decade of growth in the Partnership Wild and Scenic River Program. This voluntary conservation approach to river protection emerged in the NPS in the 1990s [20] and flourished in the mid-1990s and 2000s with the support of Congress's ongoing support for new PWSRs [21]. In contrast to EPA, the NPS had statutory authority to support collaborative efforts to protect rivers through Section 11(b)(1) of WSRA: "The Secretary of the Interior, the Secretary of Agriculture, or the head of any other Federal agency, shall assist, advise, and cooperate with States or their political subdivisions, landowners, private organizations, or individuals to plan, protect, and manage river resources" [1]. At NPS, funding and technical assistance for WSR studies was provided by its Rivers, Trails, and Conservation Assistance program [18] (p. 3), supported through annual appropriations by Congress [22].

Leadership on voluntary conservation approaches from the Executive Branch of government alone were not durable. The Clinton Administration's policies to promote collaborative watershed management were not sustained into the Bush Administration, nor were they adopted and funded by Congress. However, where Congress had pre-existing statutory authority in WSRA, a willing federal agency in NPS, and political support from its appropriators, collaborative watershed management expanded over several decades.

\subsection{Wild and Scenic River Designation and Water Quality}

WSRA directs the administering federal agency to cooperate with "water pollution control agencies for the purpose of eliminating or diminishing the pollution of waters of the [designated] river" in Section 12(c) [1]. However, WSRA does not grant jurisdiction for water quality regulation to the agency administering the designated river. Instead, water quality is regulated via the CWA, through the EPA and authorities delegated to state agencies. With this bifurcated institutional arrangement to protect water quality on designated WSRs, has WSR designation resulted in water quality maintenance or pollution reduction?

The documentation of water quality improvement following WSR designation is limited, and primarily comes from anecdotal accounts. One example anecdote from the PWSR program, is water quality improvement from increased standards at wastewater treatment plants following designation of the Sudbury, Assabet, and Concord Wild and Scenic Rivers [23]. More widely reported is the use of WSRA to limit land use activities along WSR corridors managed directly by federal agencies.

Federal land and river managers have taken action to limit mining, grazing, and logging on federal lands along or proximate to designated Wild and Scenic River corridors, often on the presumption that their continued operation or expansion could undermine 
water quality [24-26]. Case law has upheld the authority of federal agencies to deny land uses and discharges that can impact water quality degradation, including activities outside of designated segments [27].

While federal agencies have had success influencing land use activities via WSRA, there has been limited success in directly engaging in pre-existing and emergent non-point source pollution issues.

For example, during the eligibility study for the Little Miami River, the Department of Interior (DOI) initially determined that poor water quality prevented eligibility on the lower reaches of the river [28]. WSR designation first occurred in 1973, as a stateadministered national WSR, and the Ohio Department of Natural Resources became the managing agency [28] (p. 48). Local stakeholders and agencies collaborated to reduce water pollution, and eventually satisfied the DOI that the river was eligible for WSR designation. Designation occurred in 1981 on its lower reaches, however, years later, water quality concerns resurfaced. A TMDL was established in 2002 due to nutrient enrichment, low instream dissolved oxygen, sedimentation, and habitat degradation [29]. The 1973 Feasibility Study had identified these water quality issues but provided no guidance for how to reduce their impact on water quality [30].

On the Little Miami River, the collaboration that achieved water quality improvements to gain WSR designation did not persist, and water quality worsened following designation. Similarly, on the St. Croix River Wild and Scenic River, a federally managed WSR flowing through a pastiche of federal, state, county and private lands, a TMDL was established after designation [31].

However, on the Buffalo National River, a large NPS unit, NPS staff established a widespread water quality monitoring network and coordinated with Arkansas environmental agencies to deploy water quality permit systems due to the concern of contamination from upstream Confined Animal Feeding Operations (CAFO) [25]. In addition to its monitoring network, NPS engaged in a protracted, and sometimes confrontational, dialogue with the state's environmental agency for over a decade to limit CAFO expansion. While WSRA envisioned inter-agency coordination, the NPS relied on the soft power of influence and not legal action to avoid water quality degradation. Eventually, the state developed a water quality permitting system for CAFOs. One CAFO was established but closed after its permit expired. Water quality declined during the CAFO's operation [25]. However, the ability of NPS to use its water quality monitoring network to detect and attribute pollution to specific stream reaches deterred further CAFO expansion, and the permitted CAFO ceased operation when it did not renew its permit.

In comparison with other goals of the WSRA, for example, to stop dam building on a designated river, the intended outcome of Section 12(c), to diminish and eliminate pollution has been elusive. Clearly, WSR designation alone is not sufficient to maintain water quality. On both the Little Miami River and St. Croix River, TMDLs were established post-designation. On the other hand, WSRA edified NPS to coordinate with state pollution control agencies to develop and enforce water quality protections to limit land uses on private lands upstream of designated river segments. However, this coordination with the state pollution control agencies ultimately did not avoid degradation of water quality.

These three cases, while limited in number, indicate several challenges inherent in the inter-agency coordination envisioned in WSRA to diminish and eliminate pollution. This includes a decrease in stakeholder engagement and agency attention to water quality postdesignation, as on the state-managed Little Miami River. Additionally, WSR designation was inadequate to result in measures to effectively protect designated rivers from nonpoint source pollution degradation on both the state-managed Little Miami River and the federally managed St. Croix and Buffalo Rivers. The case of the Buffalo National River also illustrates the difficulty to proactively prevent non-point source pollution. The influence of the NPS limited new pollution but did not entirely halt it. Designation as a Wild and Scenic River alone is not sufficient to maintain, let alone improve, water quality. 


\subsection{Formation of Partnership Wild and Scenic Rivers}

PWSRs presented a different option for managing water quality. The responsible federal agency does not directly own or control lands along the designated river corridor. Coordination is a given need. Currently the NPS is the only federal agency utilizing this approach, through the authority of WSRA Section 11(b)(1). Financial and institutional support is supplied by NPS to local governmental organizations and stakeholder organizations to coordinate a River Management Council to implement the River Management Plan. This shift of federal resources to local organizations sustained the local capacity building that formed to promote WSR designation. The Partnership River approach was an intentional, but reactive, shift by the NPS to expand the National Wild and Scenic River System in the Eastern United states in order to minimize conflicts in areas of private land ownership [20].

The lessons-learned, embodied in the PWSR approach, were hard won, emerging from protests over the use of federal eminent domain to take private land. While Section 6 of WSRA grants the federal government limited rights to condemn land, with fee payment, it is a little used provision [32]. Rather, the takings of private land for other water projects has driven public concerns about WSR designation.

In 1978, Congress directed the NPS to form the Upper Delaware WSR in an area dominated by private land ownership. This followed the federal land acquisition downstream for the Tocks Island dam project in 1962, which resulted in the condemnation of private land. The dam was never built, but the condemned land was not returned to the private land owners [33]. Eventually, the area became the Delaware Water Gap National Recreation Area and Middle Delaware WSR in 1978. Protests over the upstream Upper Delaware WSR formed over fears of the federal government using eminent domain to acquire more private lands and displace more residents [34].

The NPS responded to local contention against the Upper Delaware WSR designation by pioneering a River Management Council to jointly implement the River Management Plan (RMP) with local authorities [20,35]. An article by founders of the PWSR program, Jamie Fosburgh, an NPS employee and current PWSR Branch Chief, and Fred Akers, Director of the first PWSR, the Great Egg Harbor WSR, and Joe DiBello, described the evolution in NPS management approach: "As top-down and more collaborative, locally-driven planning and management approaches began to meld and blend, a river conservation model built on alternatives to direct federal management and administration began to take form" [20] (p. 38). In the resulting PWSR model, the NPS did not acquire land and involved local stakeholders in river management.

In 1992, the Great Egg Harbor WSR was designated as the first PWSR, whereby the NPS supported a local organization, the Great Egg Harbor Watershed Association, to form a local River Management Council to implement the RMP. The federal government retained exclusive authority over the statutory requirements of WSRA, while the Great Egg Harbor Watershed Association managed day-to-day interaction with local stakeholders, conducted educational programs, and addressed local habitat management concerns.

The PWSR approach blossomed with the increasing political popularity of voluntary conservation efforts, leading to several river designations in the 1990s and 2000s. As of 2019, there were 17 Partnership Rivers administered by the NPS, all of which are located in the Eastern U.S. in areas primarily comprised of private land ownership [36]. In a 20-year retrospective of the program, partnership river organizations indicated that the organizational capacity support from NPS was essential to their on-the-ground accomplishments, including watershed restoration projects, water quality monitoring, land preservation, habitat improvements, and education programs [37].

What emerged as a method to staunch protest over expansion of the WSR System in areas of private land ownership, became a way to engage communities in collaborative watershed management. The embedding of a voluntary, collaborative approach to watershed management envisioned, but unattained, by two Presidents, was instead achieved by NPS, with WSRA's legal backing and Congress's financial support, through a model of sustained community capacity building. 


\subsection{Partnership Wild and Scenic Rivers as a Form of Neo-Endogenous Development}

The NPS explicitly sought to counter the top-down, direct federal management of WSRs, and empower local, community-led river management [20,37] in an era when voluntary and participatory approaches to natural resource management were politically popular. In effect, NPS delegated day-to-day river management to local organizations and stakeholders, while retaining exclusive jurisdiction over WSRA's legal authorities. It also recognized that local implementation required both funding and technical expertise, providing both funding and technical assistance. Congress embraced the partnership approach to WSR management as a way to avoid top-down control and simultaneously protect private property rights and nationally significant waters. To ensure public engagement, Congress required a demonstration of local support prior to designation, and required the NPS to form River Management Councils composed of local governmental representatives and non-governmental organizations (NGOs). By retaining local landownership, empowering natural resource governance by local stakeholders, providing funding and technical assistance, and (limited) resource protection from the federal government, the NPS adopted a devolved management approach involving more local participation.

A similar evolution occurred in other industrialized countries at the time, such as those in the European Union, as nations sought more participatory program models [38,39]. For example, to counter production-driven and extractive models of agricultural and rural production, the European Union formed the Common Agricultural Policy, which was intended as a partnership between agriculture and society. Innovation in its rural development programming in the early 1990s introduced the idea of local action groups-councils of governmental, non-governmental, and business organizations - to decide upon the goals and uses for a portion of Common Agricultural Policy rural development funding through the LEADER programme. These efforts were supported by national funding, area-based, bottom-up, involved public-private partnerships, focused on cooperative and networking approaches, and sought innovation and integration across interests [40]. Researchers, such as Shucksmith (2000), observed that national investments in local capacity-building, such as LEADER, resulted in endogenous development, a bottom-up approach positioned against the top-down determination of goals and funding priorities [41]. However, Shucksmith also observed that some of these local action groups favored the interests of local elites who were already empowered, and that in response national governments sought ways to re-engage, to ensure more equitable outcomes. The resulting "middle way" approach of local prioritization and funding decisions, with the involvement of national government representatives, resulted in Ray (2001) proposing a theory of neo-endogenous development [42].

Gkartzios and Lowe (2019) reflected that neo-endogenous development was "a way of thinking about rural development and understanding how things work on the ground" to draw attention to the power struggles of local and non-local actors in rural areas [43] (p. 164). The reliance on local knowledge, networks formed through partnerships, a focus on water quality for recreation instead of industrial production, are incorporated in the PWSR model, and are key characteristics of neo-endogenous development (Table 1). 
Table 1. Comparison of Neo-endogenous development theory with the Partnership Wild and Scenic River model.

\begin{tabular}{|c|c|c|}
\hline & Neo-Endogenous Development & Partnership Wild and Scenic Rivers Model \\
\hline Key principle & $\begin{array}{l}\text { Identifying and exploiting the } \\
\text { place-based potential of localities; } \\
\text { Socio-spatial justice }\end{array}$ & $\begin{array}{l}\text { Local land use decisions; Federal protection } \\
\text { of designated rivers }\end{array}$ \\
\hline Dynamic forces & $\begin{array}{l}\text { Local-global networks and urban-rural } \\
\text { flows; External interconnections } \\
\text { through multi-scalar and } \\
\text { multi-sector governance }\end{array}$ & $\begin{array}{l}\text { Proactive protection and management of } \\
\text { nationally significant waters, often in areas } \\
\text { with development pressure; multi-sector } \\
\text { governance; network development and } \\
\text { partnership formation }\end{array}$ \\
\hline Functions of rural areas & $\begin{array}{l}\text { A mosaic of consumerist and (re-) } \\
\text { emerging productivist functions }\end{array}$ & $\begin{array}{l}\text { Shift of rivers usage from industry to } \\
\text { recreation, while retaining agriculture }\end{array}$ \\
\hline Major rural development problems & $\begin{array}{l}\text { Unequal relations between localities } \\
\text { and external forces and institutions; } \\
\text { Climate change and economic crises. }\end{array}$ & $\begin{array}{c}\text { Managing external development pressures to } \\
\text { nationally significant waters; Coordinating } \\
\text { local land use decisions to avoid degradation } \\
\text { of designated rivers }\end{array}$ \\
\hline Focus of rural development research & $\begin{array}{l}\text { Action and activist research with } \\
\text { communities' Inter/transdisciplinary }\end{array}$ & $\begin{array}{l}\text { Involvement of local (multi-sector) } \\
\text { stakeholders in water quality research }\end{array}$ \\
\hline Sources of knowledge & Place-based "vernacular expertise" & Local knowledge; NPS technical assistance \\
\hline Sources & Lowe et al. (2018) [44] (p. 31) & Fosburgh et al. (2008) [17]; NPS [34] \\
\hline
\end{tabular}

Application of the neo-endogenous development approach to the PWSR model reveals and highlights the "missing link" for sustained non-point source pollution reduction. The CWA is often characterized as a top-down approach involving a "command and control" approach to water quality improvement. Many scholars identified the lack of sustained, multi-sectoral partnerships as a critical short-coming in the CWA's approach to managing non-point source pollution $[8,9,13,16]$. By contrast, the melding of the "top-down" and "bottom up," of the PWSR model, with its capacity-building investments by NPS, allows a different, participatory framework for durable water quality protection. We posit that the capacity-building investments made by Congress, and supported by NPS, sustained mobilization to improve water quality on the Musconetcong River, in partial attainment of CWA goals to manage and reduce non-point source pollution.

\section{Methodology}

Single case studies are generally considered best suited for descriptive work in an area where there is little primary research on the topic and for which a deeper analysis can provide a critical case frame research and develop theoretical insights [45,46]. We utilize a multi-disciplinary approach to develop this case study, including a documentary analysis, interviews of landowners and agencies, and water quality data.

Primary source documents were utilized to develop the case study. These include publicly available reports and minutes of the Musconetcong River Management Council (MRMC). These documentary sources are produced by public agencies and organizations, with the input of multiple people (e.g., minutes of meetings from the MRMC are taken at each meeting and approved by vote at the following meeting). Similar key documents, such as the Musconetcong WSR Study, were produced by the Musconetcong Advisory Committee (MAC), reviewed by the NPS, and then published as both written reports and electronically online. Other reports came from organizations and agencies, such as the NJDEP. These documents provide a contemporaneous record of events (from three decades ago) and often cross-reference each other. This allows for the triangulation of sources [47]. One limitation of our documentary sources is the reliance upon documents that form an "official" record, such as meeting minutes or agency reports. Thus, this case study does not seek to identify divergent points of view that were not contained in these documentary sources. 
Interviews were conducted of three stakeholder groups: farmland owners in the Hampton to Bloomsbury area, homeowners that participated in a septic owner outreach program (which operated 2015-2017), and public land managers (state and county) and are reported in Miller et al. (forthcoming) [48]. It was from these interviews that the authors learned the formative role of the Musconetcong Watershed Association formation and National Wild and Scenic River designation as the motivation to adopt conservation practices. This observation, as part of an iterative research process [46], led the development of this case study. Additionally, researchers attended three meetings of the MRMC and three meetings of the Musconetcong River Restoration Partnership (MRRP), the two main collaborative partnership institutions in the Musconetcong watershed. Water quality researchers and social science researchers engaged these bodies in collaborative discussions on water quality concerns and feedback on water quality data at three MRRP meetings in February 2018, August 2018, and December 2019. Participant observation of MRMC meetings was conducted on October 2017, April 2018, and December 2019.

Water quality monitoring was conducted in 2018 on an approximately 7-mile segment of the Musconetcong River between Hampton Borough and Bloomsbury Borough, New Jersey, including both main stem and tributary monitoring locations. As part of RP13-027, a 319(h) implementation grant from NJDEP "Implementation of the Musconetcong River Watershed Restoration Plan," several water qualities of concern (i.e., pH, dissolved oxygen, total phosphorus, total suspended solids, and E. coli) were monitored post installation of watershed restoration projects. Additionally, Microbial Source Tracking (MST) was utilized to identify species sources of fecal contamination. Water quality methodologies and outcomes are fully reported in Wu et al. (forthcoming) [49] and Hsu, Wu et al. (forthcoming) [50], and were related to land use land cover geospatial data ( $\mathrm{Hsu}, \mathrm{Yu}$, and $\mathrm{Wu}$ (forthcoming)) [51]. Additionally, the role of citizen science engagement is reported in (Field-Juma and Roberts-Lawler (forthcoming)) [52].

\section{The Musconetcong Partnership Wild and Scenic River Case Study}

\subsection{Introduction}

A case-study of the Musconetcong WSR designation illustrates how local capacity building, both before and after designation, sustained and expanded the initial mobilization efforts' core issues.

On the Musconetcong River, the WSR designation process was proceeded by several distinct phases, each of which ends by critical outcome, defined by NPS's implementation of WSRA. In addition to outcomes, engagement processes, and the stakeholders engaged varied. We characterized these phases as follows:

- Pre-Feasibility Study Mobilization. This time period is when stakeholders mobilized to seek WSR designation, engaged with NPS to determine edibility for WSR designation, and demonstrated community interest for WSR designation. At the conclusion, NPS prepared an Assessment of Eligibility Classification report.

- WSR Feasibility Study Process. WSRA allows for Feasibility Studies to determine the suitability of a river for WSR designation. The Study is both a process, and an outcome. The Study involves the substantial participation of stakeholders and the local community, and results in the Feasibility Study Report. During this phase, NPS provides support to organizations managing or supporting the Feasibility Study process, and the required RMP is developed.

- $\quad$ Post-Study; Pre-WSR Designation. During this time period, NPS forwarded the Feasibility Study report, along with a recommendation for WSR designation to Congress. A lull in local activity occurred as NPS retracted financial support as Congress deliberated.

- Post-Designation Implementation. Following designation, formal requirements, such as the formation of a Cooperative Agreement, appropriation of funds by Congress, and formation of a River Management Council, occurred and, once established, continued onward. Other outcomes were also observed, such the establishment of an office 
and meeting space and the transition of partnerships from informal or project-based arrangements into ongoing partnerships spanning individual projects.

Many activities established in the Post-Designation Implementation phase continued onward to the present day, following patterns set during this phase. These phases are indicated in Table 2 and are related to the Musconetcong WSR's development, drawn primarily from the Feasibility Study Report [53], RMP [18], minutes of the MRMC [54-58], MWA website [59], and funding history of the PWSR program [22].

Table 2. Summary of key events in the development of the Musconetcong Partnership Wild and Scenic River.

\begin{tabular}{|c|c|c|c|c|}
\hline Phase & Duration & Key Processes & Key Outcomes & Stakeholders Involved \\
\hline $\begin{array}{l}\text { Pre-Study } \\
\text { Mobilization }\end{array}$ & 1991-2001 & $\begin{array}{l}\text { - } \quad \begin{array}{l}\text { organizational formation } \\
\text { and formalization }\end{array} \\
\text { multi-sector stakeholder } \\
\text { meetings and consultations } \\
\text { - } \quad \text { NPS technical assistance } \\
\text { - } \quad \text { NJDEP engagement } \\
\text { NJDEP disengagement }\end{array}$ & $\begin{array}{ll}\text { - } & \text { MAC organized } \\
\text { MWA incorporated in } 1992 \\
\text { into non-profit organization } \\
\text { annual volunteer river } \\
\text { clean-up program began } \\
\text { Musconetcong Greenway } \\
\text { Corridor land preservation } \\
\text { priority area defined } \\
\text { by NJDEP } \\
\text { WSR Resource Assessment } \\
\text { and Eligibility Classification } \\
\text { Report completed by NPS }\end{array}$ & $\begin{array}{ll}\text { - } & \text { local residents of } \\
\text { - } & \text { different backgrounds } \\
\text { - } & \text { businesses and farmers } \\
\text { - } & \text { counties } \\
\text { - } & \text { NGOs } \\
\text { - } & \text { state wildlife, land } \\
& \text { preservation, and water } \\
\text { - } & \text { quality agencies at NJDEP } \\
& \text { NPS }\end{array}$ \\
\hline
\end{tabular}

\begin{tabular}{|c|c|c|c|c|}
\hline WSR Feasibility & 1998-2004 & & & \\
\hline Study Process & & $\begin{array}{ll}\text { - } & \text { river corridor } \\
\text { resident survey } \\
\text { stakeholder engagement via } \\
\text { - } \quad \text { workshops } \\
\text { leadership from the } \\
\text { multi-sector MAC } \\
\text { - } \quad \text { deliberative processes } \\
\text { formal municipal } \\
\text { engagement } \\
\text { NPS provides funding to } \\
\text { support Study process }\end{array}$ & $\begin{array}{ll}\text { - } & \text { public support identified for } \\
\text { river protection } \\
\text { - } \quad 3 \text { eligible WSR } \\
\text { segments identified } \\
\text { - } \quad \text { RMP developed } \\
\text { roles identified for NGOs, } \\
\text { local governments, state } \\
\text { government, and the NPS } \\
\text { Resolutions of support from } \\
13 \text { of } 14 \text { river corridor } \\
\text { municipalities }\end{array}$ & $\begin{array}{ll}\text { - } & \text { local residents } \\
\text { - } & \text { MAC } \\
& \text { Conservancy, and } \\
& \text { other NGOs } \\
\text { - } & \text { municipalities } \\
\text { - } & \text { counties } \\
\text { - } & \text { NPS }\end{array}$ \\
\hline
\end{tabular}

\begin{tabular}{|c|c|c|}
\hline $\begin{array}{l}\text { Post-Study; } \\
\text { Pre-WSR } \\
\text { Designation }\end{array}$ & 2004-2006 & $\begin{array}{ll}\text { - } & \text { MAC ends } \\
\text { - } & \text { leadership from MWA } \\
\text { - } & \text { NPS financial support ends }\end{array}$ \\
\hline
\end{tabular}

- $\quad$ North Jersey Resource,

Conservation, and

Development (NJRCD) applies for restoration plan funding from 319(h) program

- $\quad$ planning for Gruendyke and Seber dam removals

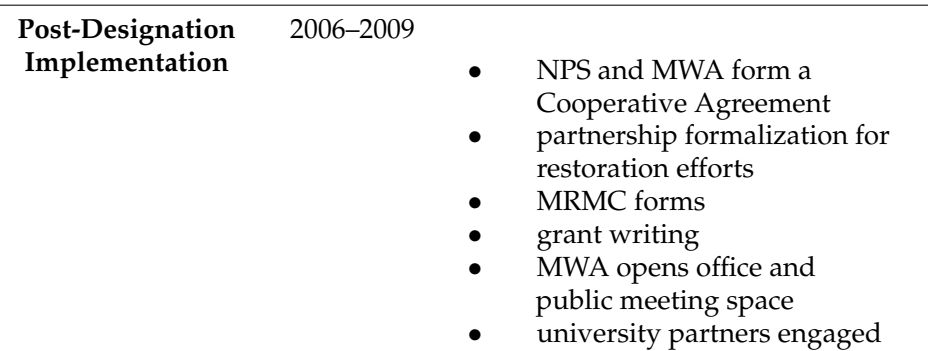

- Designated WSR on Segments A and B

- $\quad$ NPS provides funds to MWA in 2008

- $\quad$ Gruendyke and Seber Dams removed

- $\quad$ MRRP forms

- $\quad$ NJRCD forms partnership with Rutgers University to conduct water quality monitoring and develop restoration plan
- MWA, NJRCD, Trout Unlimited, NJ Audubon, American Rivers

- landowners

- municipalities

- counties

- NJDEP

- USDA

- US Fish \& Wildlife Service (USFWS)

- National Oceanographic and Atmospheric Administration (NOAA)

- NPS 
Local stakeholders were able to successfully navigate the WSR designation process. The Feasibility Study Report recommend designation of 3.5 miles as Scenic (Segment A), 20.7 miles as Recreational (Segment B), and 4.3 miles as Recreational (Segment C), as shown in Figure 1. Outstandingly Remarkable Values were identified regarding regionally important cultural, historical, scenic, recreational, and wildlife habitat resources. Congress passed the Musconetcong Wild and Scenic Rivers Act on 22 December 2006, designating Segments A and B (24.2 miles), and allowing Segment C (4.3 miles) to be designated once local support was demonstrated [60]. At the time of designation, 13 out of the 14 river-front municipalities had passed resolutions of support for the designation, which resulted in Segment $C$ not being designated [53] (p. 4). In 2018, the last municipality provided support for designation [61]. At the time of publication, the Secretary of Interior had not yet designated Segment C, though the NPS indicated the designation was proceeding in 2020 [62].

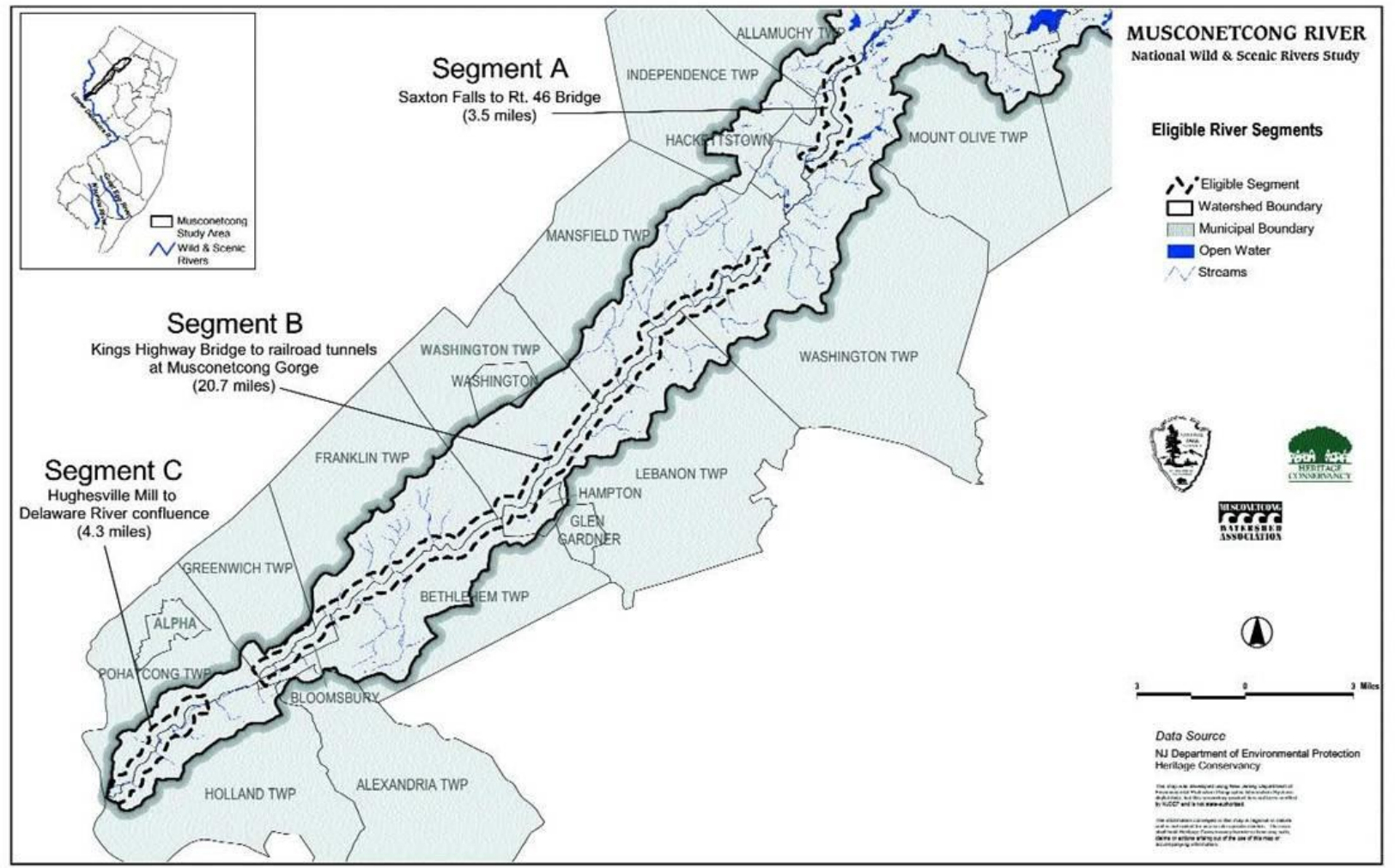

Figure 1. Musconetcong River segments eligible for Wild and Scenic River designation [53] (p. 107).

\subsection{Musconetcong River Capacity Building}

There are several elements of capacity building and changes in capacity that occurred through the Musconetcong's pre- and post-designation phases.

First, the NPS, guided by WSRA, provided a structured process of achievable milestones which supported community engagement. WSRA requires that a federal agency determine eligibility, suitability, and community support for WSR designation. NPS did not conduct these assessments in a single stage. Instead, NPS drew out these steps, allowing them to proceed separately and linearly. Each step built on the previous step. This added time to the designation process, which spanned 16 years. However, local capacity was not overwhelmed with an overly bureaucratic or technical process which proceeded too quickly for stakeholders to meaningfully engage in the process. Additionally, the skills required for local stakeholders to participate were within their reach. For example, much of the main work for those locally leading the WSR designation was consultation with local governments; organizing and conducting meetings with stakeholders, residents, and business interests; and the development of RMP. The steps toward designation were 
accessible, and not overly bureaucratic or technical. The milestones could be achieved through community organizing and meeting facilitation skills. These combined factors supported and facilitated the continued engagement of local residents and stakeholders during their 16-year designation journey. On the Musconetcong PWSR, the NPS framed a process that provided "bite-sized" milestones that could be achieved by the participation and leadership of local residents, stakeholders, and organizations.

Second, the consistency of agency support and structure of support were critical factors in the development of local capacity. The NPS had legal authority from WSRA to provide funds to identify and recommend rivers for WSR designation. This support was structured by lessons-learned of contested top-down interventions and proceeded through the PWSR approach of leadership from local entities in collaboration with the NPS [20]. Capacity and partnerships increased with the support of funding and technical assistance and diminished when funding was not available. The growth in partnerships is most evident in the Post-Designation Implementation phase, as indicated above. However, there was a lull between the Feasibility Study's completion and WSR designation when there was not NPS funding. Water quality and dam removal activities proceeded during this phase. However, they were diminished. New work proceeded, limited to planning and funding, but not project implementation. Similarly, the smallest number of stakeholders were engaged in the Post-Study Pre-Designation phase, and these engagements were narrowly aligned toward conservation interests. Funding, and the structure of that funding-to support local leadership and cross-sector partnership formation-was critical to the outcome of local capacity building.

Differences between federal and state engagement strategies became evident as materials were reviewed. For example, as indicated in the Introduction, two Presidential Administrations attempted to support a shift toward a participatory, collaborative approach for watershed management, including the Clinton Administration providing funding for this purpose through the CWA in the late 1990s. NJDEP implemented a Watershed Planning program during 1998-2000, and engaged with the Musconetcong Advisory Committee [18] (pp. 5-6, 35). However, that engagement ceased after funding for the Watershed Planning program ceased. Long-term capacity did not appear to develop from the Watershed Planning program.

Where NJDEP had sustained funding - for land preservation—it was more successful in supporting the goals of protecting water quality along the Musconetcong River via its Green Acres program. In fact, the NJDEP sought to validate its Green Acres land acquisition program by promoting greenways along the WSR corridors as "rallying points" for public land preservation [63] (p. 69). Specifically, for the Musconetcong River, the NJDEP indicated that "The Musconetcong is one of New Jersey's most important trout waters. Preserving the water quality ... is a major goal of the project" [64] (p. 54) and had spent a total of USD 7,000,000 toward this goal by 2007 [65]. Despite the significant funding of the Green Acres program, these projects were not aimed at building local capacity, and while supportive of WSR goals, did not add local capacity.

When agencies had statutory support for engaging stakeholders and forming partnerships, combined with sustained funding, capacity increased over time. Short-lived efforts without the backing of law and inconsistent funding did not develop local capacity, as was the case of the Watershed Planning program. Where both statute and funding were sustained, but collaboration was not part of the program design, in the case of Green Acres, local capacity did not increase. Critically, support for partnership formation and collaboration without funding, as happened in the lull prior to WSR designation, resulted in diminished capacity. With the backing of law, funding, and a commitment to partnership formation, the NPS was able to provide consistent support-as funder, advisor, and participant-that undergirded local capacity building for the Musconetcong PWSR.

Third, new institutions developed and formalized over time, and further enhanced local capacity building. In the pre-mobilization phase, both the MWA and MAC formed. While MAC was formed to support the WSR designation process, the MWA formed because 
"The founders saw the need for a locally-based organization, composed of individuals of different backgrounds who held a common goal of promoting a watershed-based approach to land and river resource management" [59]. Other institutional arrangements were catalyzed through official steps in the WSR designation process, including the Feasibility Study and post-designation implementation.

With regard to water quality and watershed management, the Feasibility Study Report indicated that "Cooperation in watershed management is critical for this river in that the river is the boundary of four counties and includes parts of 25 local municipalities" due to increasing development pressure, stormwater runoff, and water quantity needs [53] (pp. 22,23). The Feasibility Study Report concluded with a summary of actions for local governments: "A River Management Committee will be created to facilitate the implementation of the plan. Local governments will be requested to appoint a representative to participate in this committee to enhance cooperation and coordination in addressing river-related issues affecting all watershed residents" [53] (p. 37).

During the Study process, the RMP was developed and became the initial management document following designation in 2006. The RMP identified five management priorities: (1) recreation and scenic resources, (2) historic and archeological resources, (3) farmland and open space preservation, (4) natural resources, and (5) water quality. The RMP specified roles and responsibilities for state, local, and county governments, as well as non-government organizations to carry out these management activities. Adherence to the RMP was provided through resolutions adopted by 13 of 14 municipalities in the eligible WSR segments [53] (pp. 4).

Post-designation, the NPS formed a legal contract with the MWA to implement the RMP. The NPS entered into a five-year Cooperative Agreement with the MWA, which has been renewed in subsequent years. The Agreement enshrines the NPS's partnership approach as its main objective, citing the WSRA, the MWA's past role, and the role of the NPS in building the long-term capability of the MWA:

"The objective of the Cooperative Agreement is to stimulate the long-term capacity of MWA and the communities that MWA serves to plan for the conservation and management of the Musconetcong Wild and Scenic River and its natural, cultural and recreational resources, consistent with the purposes of Section 11(b)(1) of the Wild and Scenic Rivers Act, and as specified in PL109-452, which established the Musconetcong Wild and Scenic River, to be implemented through cooperative agreements. MWA is uniquely positioned as the local planning entity that ties the Musconetcong River communities together and has a longstanding history of planning in concert with those communities for the future of the Musconetcong River. This Cooperative Agreement will serve to both bring the best available planning and conservation expertise to the implementation of the Musconetcong Wild and Scenic River CMP, and to strengthen the long-term capability of MWA, the local communities, and the other partner organizations of the Musconetcong River to plan for and protect the Musconetcong River". [66]

Annual work plans were developed, which included the MWA's facilitation of the MRMC. Undergirded by funding from NPS, the funding stability allowed MWA to acquire additional fundraising, formalize partnerships, and engage in long-range planning.

With the NPS funding, the MWA was able to make its Executive Director staff position full-time. This, in turn, enabled the capacity to apply for, secure, and manage larger grants, including those for adaptive re-use of an abandoned storehouse along the Musconetcong River. With the conversion of the storehouse into the River Resource Center in 2009, it became MWA's office and a meeting space for the MRMC. The physical presence put MWA on the map as a destination for learning about the river for school groups, hikers, and paddlers, and the grounds contained a hiking trail and a demonstration site for native plant and riparian plantings.

Partnerships also solidified in the Post-Designation Implementation phase. The informal array of groups that worked to advance the Seber and Gruendyke dams formed into the Musconetcong River Restoration Partnership, including funders, engineers, private 
landowners, NGOs, and permitting agencies. Through the collaborative planning in the MRRP, technical support, and engagement with funders, MWA and its partners were able to engage in multi-year planning for the removal of three dams, conducted between 2011 and 2016. Their removal resulted in the restoration of free-flowing conditions supporting river recreation and the return of anadromous fish from the Delaware River [67]. With the advent of the MRRP, the NPS updated its work plans with MWA, and later its Cooperative Agreement, to ensure the continued facilitation of the successful partnership.

Fourth, a post-designation reputational bounce occurred indicating the symbolic value of WSR designation for both raising the status of the river's resources and the status of those who had advanced the designation. For example, new relationships developed with prominent federal agencies and a national NGO, American Rivers, joined efforts to restore the Musconetcong's water quality. With the completion of dam removals in 2011 at Riegelsville and Finesville in 2012, 4 miles of the Musconetcong River opened for anadromous fish passage from the Delaware River. This regional impact increased awareness of the Musconetcong River among conservation partners working on river restoration projects with the region's largest private water quality funder. In 2013, the William Penn Foundation, (Philadelphia, Pennsylvania), invited MWA into a multi-sector restoration project. This invitation, in turn, resulted in the MWA being invited onto the Steering Committee for the Coalition for the Delaware River watershed in 2014, a newly formed, four state coalition supported by the William Penn Foundation to advance federal river restoration policies. In 2016, Secretary of Interior, Sally Jewell, held a press conference for the initial notching of the next upstream dam's removal [68]. As a national Wild and Scenic River, the Musconetcong river garnered the attention of additional federal agencies, national and regional conservation organizations, private philanthropy, and even the Secretary of the Interior. Thus, the WSR designation served as a platform for reputational enhancement, resulting in a virtuous cycle of additional resources and partnerships to support the water quality improvements on the Musconetcong River.

With WSR designation achieved, consistent funding from the NPS (which grew in parity to other PWSRs by 2017), formal agreements, and the development of institutions that embraced local participation and multi-sector collaborative partnerships, the initial community mobilization that was a germ of an idea in 1991 was sustained for nearly three decades.

\section{Non-Point Source Management and Water Quality Restoration}

While stakeholders in the Musconetcong watershed were pursuing WSR designation, water quality on the Musconetcong was worsening due to road building and urbanization [69]. Non-point pollution resulted in the river no longer supporting primary contact recreation by 1998 [70]. In the 2003 RMP, impairments for ammonia, temperature, fecal coliform, $\mathrm{pH}$, total phosphorus and various heavy metals (some naturally occurring) were referenced, and several actions were recommended for non-point source pollution reduction [18]. However, in contrast to the PWSR designation being a community-led response to concerns about the development and the potential for water quality decline, the processes around non-point source regulation did not involve stakeholders, and proceeded through bureaucratic processes guided by science and the CWA (Table 3). Following the TMDL development in 2003, the completion of the Feasibility Study in 2004, local stakeholders soon engaged in projects to address non-point source pollution. 
Table 3. NJDEP actions leading to TMDL development.

\begin{tabular}{|c|c|c|c|}
\hline Duration & Activity & Outcome & Stakeholders Involved \\
\hline \multicolumn{4}{|l|}{ 1980-1996 } \\
\hline & $\begin{array}{l}\text { bi-annual scientific assess- } \\
\text { ment of water chemistry } \\
\text { and habitat }\end{array}$ & $\begin{array}{l}\text { - bi-annual water quality reports } \\
\text { water quality in upper and middle } \\
\text { watershed declines to secondary contact } \\
\text { recreation uses } \\
\text { water quality impaired for temperature, } \\
\text { pH, bacteria, and habitat in middle and } \\
\text { upper watershed } \\
\text { lower water maintains primary contact } \\
\text { recreation water quality }\end{array}$ & - NJDEP \\
\hline
\end{tabular}

1998

- $\quad$ scientific assessment of water chemistry and habitat

- Musconetcong River added to impaired waters 303(d) list

- $\quad$ Recommended for further monitoring during 2000-2001

- $\quad$ NJDEP Watershed Planning program forms
- water monitoring sites decline from 24 to 5 by 1998

- $\quad$ water quality remains impaired in upper and middle watershed

- lower watershed declines to secondary contact recreational use
- $\quad$ scientific assessment of water chemistry and habitat

- $\quad$ NJDEP Watershed Planning program ends
3 water quality monitoring sites

- $\quad$ water quality remains impaired

- $\quad$ secondary contact recreational use
- NJDEP

- NJDEP

water monitoring sites temporarily increase to 10

- $\quad$ water quality remains impaired for habitat, phosphorous,

bacteria, temperature
- $\quad$ scientific assessment of water chemistry and habitat

- TMDL development
- TMDL issued for fecal coliform bacteria

- potential sources identified include agriculture, faulty septic systems, and wildlife

\subsection{Bacteria TMDL Development (1996-2003)}

In 1996, the NJDEP published a thorough assessment of past and current water quality data (1980-1993), covering 24 sites on the Musconetcong River [69]. Most water quality degradation was attributed to increasing suburban development and roadway construction in the upper and middle portions of the watershed; water quality impacts from agriculture were decreasing. Water quality was impaired for a number of parameters in the middle and upper watershed (e.g., temperature, $\mathrm{pH}$, bacteria, habitat quality), while water quality in the lower watershed improved and attained primary contact recreational uses [69] (pp. 13-16). The NJDEP observed that water quality declines during 1992-1996 were due to increasing urban development and new roadway construction-which coincided with the motivations of the individuals that formed the MWA in 1992. 
By 1998, water quality had further declined and NJDEP listed the Musconetcong River on the 303(d) impaired waters list for several parameters, including temperature, $\mathrm{pH}$, phosphorous, and fecal coliform, based on observations at seven monitoring sites $[53,70]$. Primary contact recreation was no longer a supported use at any observed section of the Musconetcong River. By 2000, NJDEP maintained only three water quality monitoring sites on the Musconetcong River, indicating a significant decline in water monitoring capacity at NJDEP [71]. Additional water quality monitoring was proposed during 2000-2001 to support development of Total Maximum Daily Load by 2003 [70].

With additional water quality monitoring efforts, as proposed for the TMDL development, data from ten sites were reported in 2002. Impairments were observed at multiple sites for aquatic life, phosphorous, fecal coliform, and temperature [72]. Despite multiple impairments, the NJDEP issued a TMDL in 2003 only for fecal coliform bacteria on the Musconetcong River [19]. Since 2003, no new TMDLs have been proposed for the Musconetcong River, despite the RMP indicating a temperature TMDL was needed [18] (p. 35). While TMDLs for impaired waters are a requirement of the CWA, there is no federal authority to compel regulatory action, and voluntary approaches have been promoted to address non-point source pollution $[9,10]$.

Both the RMP and Feasibility Study Report indicate the impairment of the Musconetcong for several parameters, including bacteria $[18,53]$. The RMP indicated that swimming and tubing are popular activities on the river [18] (p. 19) and the Study Report indicated "high bacteria levels can be found throughout the entire length of the river, though, swimming may pose a health risk" [53] (p. 10). Despite the issuance of the bacteria TMDL on 23 September 2003, neither the RMP nor the study refer directly to the bacteria TMDL. However, the RMP indicated that, as of 2003, "a number of other efforts have focused on reducing sources of nonpoint pollution" including the use of federal agricultural conservation programs, and that "A partnership of state, county and local organizations is working to promote and install riparian buffers to improve water quality and wildlife habitat" [18] (p. 35).

\subsection{Collaborative Conservation and the Musconetcong River Restoration Partnership}

After the NJDEP's Watershed Planning program ended in 2000, it funded NJRCD, a regional nonprofit dedicated to agricultural conservation, to conduct further watershed planning [53](p. 6). NJDEP shifted to competitively awarded grants to support watershed planning efforts. In 2005, the NJRCD submitted a grant by NJDEP for non-point source pollution control via the Clean Water Act 319(h) program to develop a watershed restoration plan [73]. Following the grant's award in 2006, NJRCD formed a partnership with Rutgers University Cooperative Extension in 2007 to study water quality and recommend watershed restoration activities [73].

Restoration projects occurred while Rutgers Cooperative Extension (RCE) was conducting its water quality assessment and NJRCD developed a watershed restoration plan. Activities focused on addressing non-point pollution and the bacteria TMDL, primarily from agricultural land uses and septic systems in residential areas, with activities supported in multi-year, project-based grants.

The MRMC, once formed in February 2008, became a coordinating and informationsharing venue for these activities. Minutes from the MRMC indicate that, in 2008, the USDA Natural Resource Conservation Service (NRCS) targeted farm landowner outreach on Turkey Hill Brook and West Portal Creek in Bethlehem Township, and initiated a multi-sector partnership approach $[54,56]$. This included federal (NPS, NOAA, USFWS, USDA), state (NJDEP), and local governments, private land owners, and non-governmental organizations, including MWA, NJRCD, TU, New Jersey Audubon (NJA), American Rivers, and others.

Non-point source pollution projects and dam removal projects activities did not occur in overlapping geographic areas and initially proceeded on two separate tracks. The lower Musconetcong watershed was the most impounded section, and the Musconetcong 
Valley was its most agricultural section. However, many project partner and funder relationships overlapped. The MRRP initially focused on dam removals and included American Rivers, Trout Unlimited, NJRCD, federal agency representatives from USDA, USFWS, and NPS; state regulators and funders; private land owners, and private-sector engineers and contractors. In 2017, the MRRP expanded to include other, non-dam removal water quality improvement efforts, including fisheries habitat and non-point source water quality assessments.

\subsection{Water Quality Assessment and Restoration Plan Development}

After NJRCD received a 319(h) grant from NJDEP (RP06-073), it contracted with RCEs to conduct a water quality assessment to assess the source causes of the Musconetcong River's impairments that caused it to be listed on the 303(d) list [73]. A study area in the Musconetcong Valley, from Hampton to Bloomsbury, was selected because multiple causes of water quality impairments were highlighted in the New Jersey Integrated Water Quality Monitoring and Assessment Reports, including fecal coliform, $\mathrm{pH}$, and aquatic life. The area represented about $12 \%$ of the entire watershed, including approximately 7 river miles and 19 miles of named and unnamed tributaries. RCE indicated that "The goal of the overall project is to develop a watershed restoration and protection plan that, through its implementation, will improve water quality in the project area" [73] (p. 12). Ten monitoring sites were selected, six of which were on tributaries (including West Portal Creek and Turkey Hill Brook), to identify potential livestock and fecal bacteria sources.

In 2007, RCE collected bi-weekly water samples from May to October, with additional bacteriology sampling for an additional three times per month in June, July and August at 10 locations for water $\mathrm{pH}$, temperature, dissolved oxygen, stream width, stream depth, stream velocity, ammonia-N, nitrate-N, nitrite-N, total Kjeldahl nitrogen, total phosphorus, dissolved orthophosphate, total suspended solids, fecal coliform, and Escherichia coli (E. coli). The study results showed that some elevated water temperatures were observed throughout the watershed, as well as a small set of violations of the $\mathrm{pH}$ minimum criterion and the total phosphorus criterion. However, all samples collected throughout the Musconetcong Watershed exceeded the state criteria for E. coli. The monitoring results concluded that the Hampton to Bloomsbury segment of the Musconetcong Watershed was compromised given the continual and persistent violations of the surface water quality criteria for bacteria and the occasional elevated surface water temperatures [73].

In 2008 and 2009, subsequent Microbial Source Tracking (MST) studies were deployed to identify potential sources of fecal contamination. The results indicated that some sites had a higher incidence of contamination with human feces particularly following storm events which accumulated rainfall is known to increase runoff episodes and the inputs of microbial contamination, together with other pollutants, into waterbodies-an increasingly common issue identified in Northern New Jersey [74]. Other sites were found to have a higher incidence of contamination with bovine feces. Fecal contamination from other species were also found, including cows, but due to selection of molecular markers, potential contaminations from individual species were not evaluated. Simultaneous with these assessments, USDA NRCS conducted a riparian buffer project along the West Portal tributary with TU and NJRCD [58]. In RCE's final report, recommendations on watershed restoration were made including limiting livestock access to streams, improving manure management, increasing riparian buffer size, and starting a septic outreach program for citizens [73].

Based on RCE's findings, NJRCD developed a watershed restoration plan for the Hampton to Bloomsbury segment of the Musconetcong River as a requirement of the 319(h) funding [75]. In the restoration plan, NJRCD cited the Musconetcong RMP, stating that three goals of the RMP "would be served by the successful implementation of this subwatershed restoration plan" [75] (p. 95). With the majority of this segment's land area in active human usage for agriculture $(45 \%)$ and urban areas $(15 \%)$, recommendations focused on farms and residences, and not forestry management ( $34 \%$ of the land area). Recommended 
agricultural practices included no till and residue management, conservation buffers, cover crops, livestock exclusion fencing, development of a regional manure composting facility, and wildlife management (e.g., deer and geese). Recommendations for urban areas focused on stormwater management (e.g., rain garden installation, retention basin retrofits, roadside ditch improvements) and septic system education. Specific sites were proposed for these activities, including total land area, anticipated pollution reductions, and estimated implementation and technical costs totaling approximately USD 4,000,000 [75] (pp. 117-167). The plan also recommended that long term monitoring be conducted, including the assessment of stakeholder awareness of their land use decisions on water resources and the continuation of practices after funding ends [75] (pp. 169-170). In 2013, the NJRCD was awarded a grant by the NJDEP (RP13-027), funded via 319(h) funds, to implement the restoration plan.

\subsection{Delaware River Watershed Initiative (2013-Ongoing)}

In 2013, the William Penn Foundation included local partners (MWA, NJRCD, TU and NJA) in a funded partnership project, called the Delaware River Watershed Initiative (DRWI), with a focus on non-point source pollution prevention, land preservation, and stream restoration projects [76]. Two phases of funding were established for the DRWI, Phase I (2014-2017) and Phase II (2018-2020), with additional project funding provided to the National Fish and Wildlife Foundation [77].

William Penn Foundation funds were used to conduct a septic owner outreach program, continue riparian buffer installations, expand livestock exclusion fencing, install armored stream crossing for livestock movements, install cover crops and support technical assistance, including non-till agriculture workshops. Additionally, the Foundation required that grantees, such as MWA, NJA, TU, and NJRCD, coordinate their implementation activities, a unique feature of its funding strategy in the Delaware River Watershed Initiative [77] (Wilson, Bromer and LaRoche 2019). Approximately USD 3,000,000 was used to support outreach, technical assistance, water quality improvement projects, and water quality monitoring between 2013-2020 from the William Penn Foundation, the NJRCD 319(h) implementation grant, the National Fish and Wildlife Foundation, and federal funding from USDA NRCS and USFWS. The Hampton to Bloomsbury river segment remained a targeted area, with a focus on agricultural conservation practices for West Portal Creek and Turkey Hill Brook sub-watersheds and septic owner outreach in the Boroughs of Hampton and Bloomsbury.

\subsection{Water Quality Restoration Outcomes}

Montclair State University (MSU) was selected by the MWA to perform limited water quality and Microbial Source Tracking (MST) analyses in the Hampton to Bloomsbury area, utilizing monitoring sites selected by RCE in 2007. These small-scale bacteria and Microbial Source Tracking (MST) studies at a limited number of sites were performed from 2015 to 2017 by MWA and Montclair State University (MSU) with the funding provided by the DRWI [78]. Following this reconnaissance study, MSU was awarded a grant by the Academy of Natural Science at Drexel University, with funds originating from the William Penn Foundation, and contracted with NJRCD to utilize part of its 319(h) grant to perform an in-depth water quality assessment, largely repeating the 2007 study by RCE, and utilizing modern MST methods.

The small-scale bacteria and MST studies revisited some of the study sites, including in the original 2007 project and revealed fecal contributions by wildlife. This suggested that a more tailored monitoring project with regular sampling scheme was necessary to better understand the trends in water quality from 2007 to 2018, effectiveness of implemented Best Management Practices (BMPs), and sources of fecal contamination, and provide recommendations for future restoration directions to stakeholders with limited resources. The first adjustment adopted was to expand the panel of MST markers to include Canada goose, deer, horse, and chicken. Therefore, a new monitoring project was conducted from 
May to October 2018, replicating the same collection frequency at the same 10 locations of the original 2007 study (Figure 2). Water quality parameters tested were similar, except for total Kjeldahl nitrogen and total coliforms.

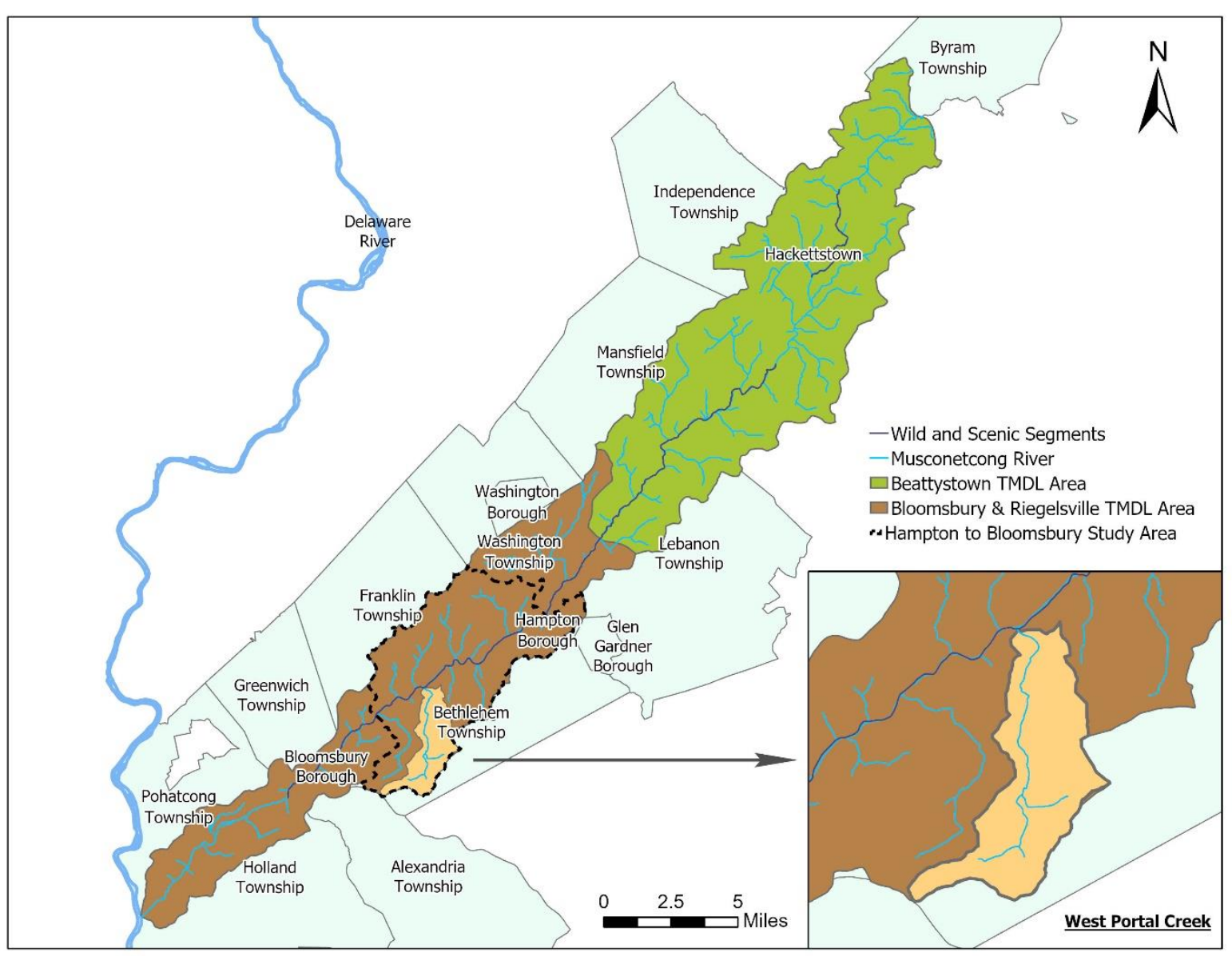

Figure 2. Hampton to Bloomsbury Study Area shown with dashed boundary; inset detail of West Portal Creek (prepared by T. David Hsu).

Where the voluntary, collaborative conservation approach proved an effective and sustainable engagement model for motivating and sustaining voluntary compliance with environmental goals was on West Portal Creek, where NGOs and federal, state, and private funding partners concentrated resources to target the majority of the tributary's farmland owners. This was the only location to attain bacteria goals specified in the TMDL. Even though the Hampton-Bloomsbury segment of the watershed is a small portion of the overall watershed, the impact of agricultural conservation activities and the septic owner outreach program were too diffuse to be observed with the water quality methods applied here. Additionally, bacteria load increased in this segment during the 2008-2018 period. While MWA and its partners had sufficient organizational capacity and resources to effectively target the sub-watershed of a single tributary, they lacked the organizational capacity and funding to replicate this strategy to multiple sub-watersheds simultaneously. Thus, the capacity to achieve water quality outcomes requires sufficient funding availability and adequate ability to form local relationships to work in coordination with multiple landowners simultaneously, in order to concentrate the potential for water quality improvements.

The results indicated that E. coli levels were significantly reduced from 2007 to 2018 for eight out of nine locations (one tributary site had an absence of water flow). Despite improved water quality in 2018, exceedances of the New Jersey Water Quality Standards re- 
mained. MST results showed fecal contamination at the study sites was mainly attributed to human activity in 2018, with sporadic substantial fecal contributions from cow and wildlife (Canada goose and deer). Horse and chicken fecal contributions were nearly negligible.

Results on the West Portal Creek showed a statistically significant decrease in bacteria by $95 \%$, surpassing the TMDL goal of a $93 \%$ reduction, and reaching attainment during some sample periods. However, significant improvements were only observed on West Portal Creek, which received the most concentrated restoration efforts, but not in the broader Hampton to Bloomsbury river segment.

The 2018 study concluded the effectiveness of BMPs as greater reductions in E. coli were observed in the area where agricultural BMPs were implemented but highlighted fecal inputs from wildlife in addition to human and cow identified from the previous 2007 study, which can be used to further develop site-specific restoration plans with de-listing the Musconetcong River from the 303(d) list as the ultimate goal.

\subsection{Participant Attitudes toward Water Quality Restoration}

Attitudes of farmland owners, residential septic systems owners, and wildlife managers involved in these targeted watershed restoration efforts were gathered in 2019 and are reported in Miller et al. (forthcoming) [48]. The farmland owner interviews indicated that the formation and presence of the MWA, as well as the NJRCD, influenced their adoption of conservation measures to improve water quality. (Emerging from the interviews was the significance of non-governmental organizations in the adoption of voluntary practices to reduce non-point source pollution from farms, and became the genesis of this article's topic following the Grounded Theory approach [46]).

Conserving soil resources was widely acknowledged by the interviewed farmland owners; most connected soil conservation to water quality. For example, a farmland owner indicated soil conservation is "like the hippocratic oath for doctors, first, do no harm. ... I think it's the role of landowners is don't do anything that's gonna hurt the river (1)." Awareness of the need for soil conservation, and soil conservation actions were widely evident among interviewed farmland owners. Miller et al. (forthcoming) indicated that the geographic features of the Musconetcong watershed (e.g., highly erodible soils, narrow watershed with steep slopes), may have predisposed farmland owners to awareness of soil loss and patterns of water flow [48].

The role of local NGOs, including the MWA and NJRCD, were cited by several farmers as important factors in their decision to conserve soil and water resources. One of the farmers interviewed was involved in the MWA's formation, and indicated that its early goal was to build awareness of the importance of on-farm conservation practices to maintain water quality:

"In the early 1990s, we started the Watershed [Association] for the awareness. Now, it started as our volunteer group and a volunteer executive director. What we were really trying to do was just identify and get people to buy in in the municipalities the uniqueness of our resource. ... In the ag[riculture], now you got land preservation, environment awareness, the agriculture interest, business interest. You gotta find a way to bridge all those gaps. The land is the resource that starts it all. So we created the Watershed [Association] for the awareness (5)."

As indicated by this farmer, MWA also conducted directed outreach activities, to engage farmers. For example, one farmer indicated that:

"Somebody from the MWA knocked on our door and said, "We know you've just bought this house and we want you to belong to the Watershed Association." So like within the first month of our being here, we realized that there were a lot of people who did feel the way that we do, despite the fact that we're in a pretty red area (1)..."

"Well, we belonged to the Musconetcong Watershed Association and we have belonged to that since we moved here. And I've worked on projects with them, like planting buffer trees at other sites along the river (1)." 
NJRCD also organized farm conservation workshops, which were cited by several farmers as important for providing formation about the technical and financial aspects of incorporating new on-farm conservation practices. Direct engagement was a critical strategy for working with farmers on West Portal Creek and Turkey Hill Brook, as well as elsewhere in the region.

The formation of the MWA, and the ongoing conservation activities did not engage all farmers; however, there is evidence of impact on those farmers as well. For example, one farmer indicated a process of "osmotic learning": "I've learned an awful lot being involved in this side, and just learned a lot by osmosis. On keep the nutrients on the ground, as much as possible, be very mindful of the runoff, and what's in the runoff" (4). Several farmers indicated similar water quality concerns including impacts downstream on trout and amphibian habitat.

The formation of the MWA, and its coordination with partners over its quarter century of outreach and partnership formation, had both direct and indirect influences of the adoption of farm conservation practices, which facilitated water quality improvements. Miller et al. (forthcoming) considered this outcome a culture of conservation, given the diffusion of conservation awareness and activities to members, with strong organizational ties, workshop participants, and bystanders who had limited direct engagement [48].

\section{Discussion}

\subsection{Is the PWSR Model a "Best Case" Voluntary Conservation Approach to Address Non-Point Pollution?}

For the Musconetcong River, PWSR designation proved effective for achieving the original goals of water quality protection and improvement that mobilized designation efforts. Further, the voluntary approach utilized by local organizations was successful in demonstrating methods to achieve the pollution reductions required by the TMDL when resources were concentrated to a targeted tributary. However, those outcomes were achieved by having the organizational capacity to raise funds successfully, form and maintain partnerships, and have a long-term presence in the watershed.

This critical role of organizational capacity aligns with a case study of the Lynnhaven River, a tributary to the Chesapeake Bay, where a local watershed association spearheaded water quality improvement to address a bacteria TMDL [13]. A critical factor of water quality improvement on this tributary to the Bay, was: "Local government engagement and local environmental groups-with their laser-like focus on improving a specific, beloved river important to their community's history, environment, and economy" [13] (p. 304). Jones (2014) indicated that the attention given to the bacteria TMDL, by the Lynnhaven River Network was like a "force multiplier," mobilizing volunteers, educating residents and recreationists, and ultimately provided the public support for local municipal officials to undertake expensive stormwater infrastructure upgrades [13] (p. 317). Similar to the Lynnhaven River Network, MWA focused on water quality improvement. Critically, the investments from NPS to MWA were a "force multiplier" enabling the MWA to increase its capacity and sustain multi-sector and inter-agency partnerships, which in turn, attracted additional private and governmental funding.

The outcome of the Musconetcong case study demonstrates a best-case approach of how to do a voluntary conservation project, as on West Portal Creek, which benefited from multisector partnerships, multi-level agency collaboration and support, and local government and stakeholder engagement. The multi-decade duration of these efforts fostered a culture of conservation amongst farmland owners, that spurred their conservation efforts. However, there were significant limitations outside of the West Portal Creek sub-watershed in the Hampton to Bloomsbury river segment, where resources-both funding and the ability to concentrate staff time for outreach-were diffuse. Further, bacteria loading increased in the Hampton to Bloomsbury segment between 2008 and 2018.

Where WSRA supported the water quality improvements on the Musconetcong River was through Section 11(b)(1), with the ability to form partnerships to muster the capacity, expertise, and funding to improve water quality, not Section 12(c), which directs federal 
agencies to coordinate with state agencies to reduce and eliminate pollution. Several researchers have noted that the long-term effectiveness of voluntary conservation approaches requires the accompaniment of strong regulation $[8,9,13]$. On the Musconetcong River, the regulation of non-point source pollution was not effective without voluntary and collaborative conservation approaches.

\subsection{Theorizing Partnership Wild and Scenic Rivers as an Example of Neo-Endogenous Development in North America}

Where the PWSR approach succeeded in improving water quality, was through providing local capacity to in order to do more.

Unlike some WSR Study processes, where federal agencies often determine eligibility, suitability, and feasibility in a single, professionally written report, the PWSR model separates these steps of the WSRA designation process. Each step became a mobilization target for local stakeholders, which were supported and guided by NPS. WSR designation mobilized local capacity building through the formation of relationships between landowners and governmental agencies, and built momentum through pre-designation milestones, established by the NPS.

As Lowe et al. (2018) indicated in their case study of rural expertise in neo-endogenous development, the NPS was "building on and building up the expertise of local actors through the joint production of knowledge, the creation of networks for expertise exchange, and helping equip local actors with methods and tools they can use to develop and apply their own expertise" [44] (p. 36). The use of a formal Cooperative Agreement and the annual work plan were not mere extensions of a top-down, bureaucratic government but enshrined the overall partnership approach, which was then modified on a regular basis to accommodate the evolution of local needs. Likewise, the River Management Council was not a just a body of municipal, county, and NGO representatives, but a space where information was shared, mutual goals were identified, and projects were conceived. Organizational capacity increased over time, forming new institutions to sustain ongoing, long-term partnerships, similar to those within the MRRP.

Through building capacity, the NPS was able to achieve, at least in part, the goal of non-point source pollution reduction that was elusive through the top-down regulation of the CWA. This way of thinking-between expert and non-expert, local and non-local actors, and multisector leadership-are hallmarks of neo-endogenous development [43]. By focusing on the people on the ground, who shared a goal of protecting nationallysignificant rivers, the NPS was able to support important water quality goals of WSRA and the CWA.

Thus, the theoretical implication of this Musconetcong case study is the effectiveness of a neo-endogenous development approach to water quality improvement. Efforts to mobilize public support to achieve non-point source pollution reduction faltered when focusing on CWA's TMDL, top-down framework, as on the Little Miami River, the Lynnehaven River, and Chesapeake Bay. Instead, sustained investments in local organizational capacity by NPS's PWSR model allowed the Musconetcong's stakeholders to succeed in making water quality improvements over nearly three decades of effort.

\section{Conclusions}

The culture and continual practice of partnership formation on the Musconetcong River, through pre-designation roundtables and municipal consultations, through to the facilitation of the MRMC and MRRP, was critical for MWA to form enduring partnerships to access technical and financial resources. Specifically, the NPS enabled neo-endogenous development through three critical processes (1-3), and a resultant reputational bounce occurred following Wild and Scenic River designation.

(1) A structured process of achievable milestones, accessible without specific technical expertise.

(2) Consistent financial support to local organizations and technical assistance. 
(3) The formation of institutions and the use of formal agreements to enshrine a partnership approach toward resource management.

(4) Reputational enhancement and increased visibility.

On the Musconetcong River, the capacity-building approach of the PWSR program set local stakeholders on a trajectory that was "right" for achieving water quality improvements as shown in the case of West Portal Creek and in river restoration projects such as dam removals.

This conclusion is bolstered by a case study of the White Clay PWSR, where it was concluded that financial resources from the NPS, the ability to leverage those funds from other funding sources, and the human resources represented by participants in the River Management Council were identified as factors promoting partnership formation [79] (p. 162). Harnessing local stakeholder knowledge, coordinating disparate public funding programs, and catalyzing public funding is what voluntary conservation proponents in the Clinton and Bush Administrations hoped to achieve through changes in CWA implementation. However, at the same time that the PWSR concept took hold at the NPS, their voluntary conservation approaches undermined the resources necessary from EPA and NJDEP for effective watershed-wide management on the Musconetcong River.

The underfunding of the PWSR program; diminished capacity at NJDEP and other governmental agencies during the 1990s, 2000s, and 2010s; a lack of engagement from agencies outside of the conservation sector (e.g., public health); and lack of financial resources, meant that the capacity to coordinate and fund conservation efforts were ultimately limited to discrete projects or sub-watershed restoration partnerships. Specifically, the lack of resources to support enough local capacity to coordinate targeted outreach to landowners on multiple tributaries simultaneously, and the lack of funding to support that capacity and that level of restoration activity, prevented water quality improvements to the targeted Hampton to Bloomsbury river segment. Thus, the efforts on the Musconetcong River could not be "right-sized" to achieve watershed-wide TMDL goals, despite deploying an effective partnership approach for voluntary and collaborative resource management. The "success" of the Musconetcong case study is a qualified one.

As on other waterbodies outside of the WSR System, water quality improvement from non-point pollution has been elusive. Neither the top-down approach of the CWA, nor the hope for effective coordination in WSRA Section 12(c) have alone been effective in non-point source pollution reduction on WSRs. Instead, on the Musconetcong River, Section 11(b)(1) — the ability to form partnerships to implement the goals of WSRA—was the most effective tool, because it built the capacity of local organizations with a "laser-like" focus on improving their river's water quality.

Voluntary approaches may yield environmental outcomes with adequate organizational capacity investments. However, without sufficient resources to reach a watershedwide scale of impact, voluntary approaches alone cannot achieve TMDL non-point source pollution reduction goals. Effective regulations, supportive monitoring and regulatory process, and adequate funding for water quality improvements are necessary for the PWSR program to effectively live up to the WSRA's goal of "eliminating or diminishing the pollution". For local, county, and state governments to reap the benefit of recreational rivers, the public sector must increase its capacity to manage and regulate its public trust resources effectively - and invest in the non-governmental organizations that form the partnerships necessary to employ voluntary conservation approaches-to achieve water quality improvements. 
Author Contributions: Conceptualization, M.W., N.R.-L. and J.M.; Data curation, A.R.H., M.W., T.-T.D.H., J.M., A.R. and L.H.L.; Formal analysis, A.R.H., M.W., T.-T.D.H., J.M. and L.H.L.; Funding acquisition, A.R.H. and M.W.; Investigation, A.R.H., M.W., T.-T.D.H., N.R.-L., J.M. and A.R.; Methodology, A.R.H., M.W., T.-T.D.H., N.R.-L., J.M. and L.H.L.; Project administration, A.R.H., M.W. and N.R.-L.; Resources, A.R.H., M.W., N.R.-L. and L.H.L.; Software, T.-T.D.H.; Supervision, A.R.H., M.W. and N.R.-L.; Validation, M.W., T.-T.D.H. and A.R.; Writing-original draft, A.R.H., M.W. and T.-T.D.H.; Writing—review and editing, M.W., T.-T.D.H., N.R.-L., J.M., A.R. and L.H.L. All authors have read and agreed to the published version of the manuscript.

Funding: Funding for this research was provided by the William Penn Foundation through the Delaware Watershed Research Fund (DWRF-17-03), managed by the Academy of Natural Sciences at Drexel University, Philadelphia, Pennsylvania; Montclair State University; and the N.J. Department of Environmental Protection (RP13-027). Funding for watershed restoration projects was provided by the U.S. Department of Agriculture Natural Resources Conservation Service, U.S. Fish and Wildlife Service, the Clean Water Act 319(h) program via the NJDEP (RP13-027), and the William Penn Foundation. Organizational capacity funding was provided by National Park Service. The views expressed are those of the authors, including any omissions or errors.

Institutional Review Board Statement: The study was conducted according to the guidelines of the Declaration of Helsinki and approved by the Institutional Review Board of Montclair State University (IRB-FY17-18-935).

Informed Consent Statement: Informed consent was obtained from all subjects involved in the study.

Data Availability Statement: Data from the water quality portion of the research is available in a publicly accessible repository Water Quality Exchange (WQX), and available for retrieval through the EPA's Water Quality Portal (WQP). Data regarding agricultural conservation practices is third Party Data. Restrictions apply to the availability of these data. Data was obtained from North Jersey Resource Conservation and Development, Inc., P.O. Box 117, Asbury NJ 08802, USA, +1 (908) 574-5368. GIS Land Use Land Cover used in this research is not new data. Data regarding interviews and focus groups are subject to privacy and ethical considerations subject to Institutional Review Board agreement and are not publicly available. Data which does not reveal identifiable information of the research participants may be made available upon request to the corresponding author. All other data requests should be made to the corresponding author.

Acknowledgments: The authors acknowledge the contributions of Christa Reeves, Kevin Olsen, Molly Hillenbrand, Kevin Zerbe, and Edward Wong for their contributions to the water quality monitoring and analysis component of this research. Laura Tessieri, Executive Director, North Jersey Resource Conservation and Development, provided guidance, support, and insight on farm conservation practices undertaken in the Musconetcong Valley. Additionally, the authors thank the Musconetcong River Management Council, Musconetcong River Restoration Partnership, and the research participants for their participation.

Conflicts of Interest: Hunt is small farm owner and resident along the Musconetcong River within the study area, received conservation assistance funding from the USDA, and did not participate in the collection and analysis of the farmland owner interviews. Both Dr. Hunt and Ms. Roberts-Lawler receive partial funding for their positions from the National Park Service. At the time of grant submission to the Delaware Watershed Research Fund, the funder requested a revision to the study design to include a greater emphasis on the human role in water quality outcomes. This resulted in the expansion of the research team to include Dr. Miller and Dr. Hunt as investigators, and methods for including stakeholder views. Other funders had no role in the design of the study. The funders had no role in the collection, analyses, or interpretation of data; in the writing of the manuscript, in the decision to publish the results, and have not reviewed pre-publication manuscript drafts. 


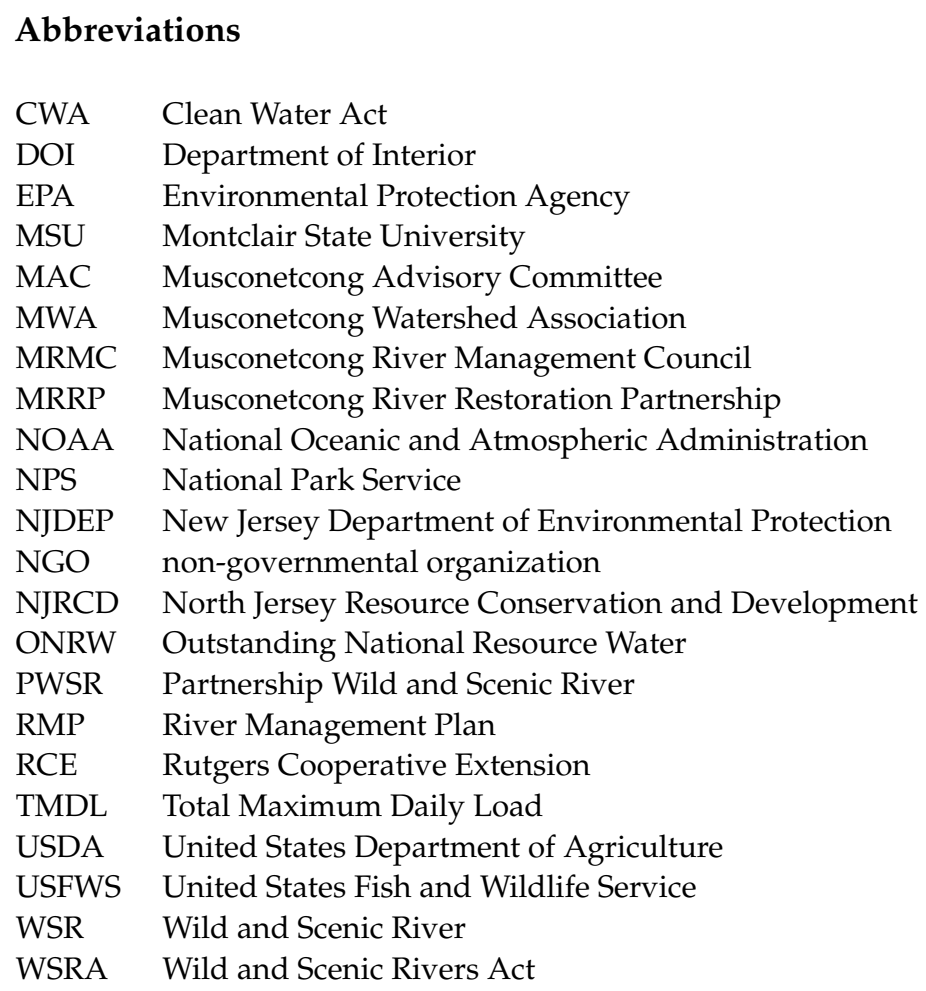

\section{References and Notes}

1. Wild and Scenic Rivers Act 1968 (as amended). Public Law 90-452. Codified at: 16 U.S.C. 1271-1287.

2. Dan Tarlock, A.; Tippy, R. The Wild and Scenic Rivers Act of 1968. Cornell Law Rev. 1970, 55, 707-739.

3. EPA. Watershed Academy Web, Introduction to Clean Water Act, Antidegradation Tier 3. Available online: https://cfpub.epa. gov / watertrain/moduleFrame.cfm?parent_object_id=2650 (accessed on 4 February 2021).

4. EPA. Office of Water, Memorandum "EPA Designation of Outstanding National Resource Waters" from William R. Diamond, Acting Director, Criteria and Standards Division. 1989. Available online: https://www.epa.gov/sites/production/files/2014-10/ documents / diamond-outstanding-memo.pdf (accessed on 4 February 2021).

5. Brawer, J.M. Antidegradation Policy and Outstanding National Resource Waters in the Northern Rocky Mountain States. Public Land Resour. Law Rev. 1999, 20, 13-30.

6. Interagency Wild and Scenic Rivers Coordinating Council. Evaluation of State Water Quality Assessments and the National Wild and Scenic Rivers System; Interagency Wild and Scenic Rivers Coordinating Council: Washington, DC, USA, 2018 ; p. 112.

7. Stiles, T.C. Lighting a new candle: A new long-term vision for the clean water act section 303(d) program. J. Am. Waters Resour. Assoc. 2014, 16, 1-8.

8. Layzer, J.; Rinfret, S. The Environmental Case Translating Values into Policy, 5th ed.; SAGE: London, UK, $2019 ;$ p. 664.

9. Williams, D.R. When Voluntary, Incentive-Based Controls Fail: Structuring a Regulatory Response to Agricultural Nonpoint Source Water Pollution. Wash. Univ. J. Law Policy 2002, 9, 21-121.

10. Blumm, M.C.; Warnock, W. Roads Not Taken: EPA vs. Clean Water. Environ. Law 2003, 33, 79-112.

11. President's Council on Sustainable Development. Sustainable America: A New Consensus for Prosperity, Opportunity, and a Healthy Environment for the Future; 1996; p. 202. Available online: https://clintonwhitehouse2.archives.gov/PCSD/Publications/TF_ Reports/amer-top.html (accessed on 4 February 2021).

12. EPA; USDA. Clean Water Action Plan: Restoring and Protecting America's Waters; 1998; p. 110. Available online: https://nepis.epa. gov/Exe/ZyPDF.cgi/20004J7S.PDF?Dockey=20004J7S.PDF (accessed on 4 February 2021).

13. Jones, S.C. Making Regional and Local TMDLs Work: The Chesapeake Bay TMDL and Lessons from the Lynnhaven River. William Mary Environ. Law Policy Rev. 2014, 38, 227-317.

14. Sierra Club; U.S. EPA. United States District Court, Maryland. 2001. Available online: https://law.justia.com/cases/federal/ district-courts/FSupp2/162/406/2320229/ (accessed on 4 February 2021).

15. NJDEP. New Jersey's Vision Approach for Assessment, Restoration and Protection of Water Resources under the Clean Water Act Section 303(d) Program. 2019, p. 34. Available online: https://www.state.nj.us/dep/wms/bears/docs/Appendix_G_\%20NewJersey_ Vision_Approach.pdf (accessed on 4 February 2021).

16. GAO. Clean Water Act Changes Needed if Key EPA Program Is to Help Fulfill the Nation's Water Quality Goals. 2013 ; p. 108. Available online: https:/ / www.gao.gov/assets/660/659496.pdf (accessed on 4 February 2021).

17. Council on Environmental Quality. Cleaner Water. 2004. Available online: https://georgewbush-whitehouse.archives.gov/ceq/ clean-water.html (accessed on 4 February 2021). 
18. MAC. Musconetcong River National Wild and Scenic Rivers Study River Management Plan; MAC: Washington, DC, USA, $2003 ;$ p. 74.

19. NJDEP. Total Maximum Daily Loads for Fecal Coliform to Address 28 Streams in the Northwest Water Region; 2003; p. 78. Available online: https://www.nj.gov/dep/wms/bears/docs/Northwest\%20FC.pdf (accessed on 4 February 2021).

20. Fosburgh, J.; DiBello, J.; Akers, F. Partnership Wild and Scenic Rivers. Georg. Wright Forum 2008, 25, 37-44.

21. River Network. Celebrating 40 Years: The Wild and Scenic Rivers Act. River Voices 2008, 18, 36. Available online: https://www. rivernetwork.org/wp-content/uploads/2016/04/River-Voices-v18n3-2008_The-Wild-and-Scenic-Rivers-Act.pdf (accessed on 4 February 2021).

22. Akers, F. Partnership Wild and Scenic Rivers Funding History, Greenbook Format, \$ in Thousands (FY 1998-FY2020); $2019 ;$ p. 1.

23. NPS. River Connections [video recording]. 16:23 minutes. 2018. Available online: https://www.nps.gov/articles/riverconnections.htm (accessed on 4 February 2021).

24. Interagency Wild and Scenic Rivers Coordinating Council. A Compendium of Questions E Answers. Bureau of Land Management. 1997. Available online: https://lowerfarmingtonriver.org/docs/Learn-CompendiumofQuestions\&Answers.pdf (accessed on 4 February 2021).

25. Mott, D.N. Permitted Concentrated Animal Feeding Operation Assessment Buffalo National River. Buffalo National River Alliance; AR, USA. 2016, p. 95. Available online: https://buffaloriveralliance.org/resources/Pictures/Final\%20Draft\%20Mott\%20Report\% 20\%20.pdf (accessed on 4 February 2021).

26. Keith, J.; Jakus, P.; Larsen, J. A Report for the Utah Governor's Public Lands Policy Coordination Office; Department of Applied Economics, Utah State University: Logan, UT, USA, 2008; p. 65.

27. Blumm, M.C.; Yoklic, M.M. The Wild and Scenic Rivers Act at 50: Overlooked Watershed Protection. Mich. J. Environ. Adm. Law 2020, 9, 1-76. Available online: https://repository.law.umich.edu/mjeal/vol9/iss1/2 (accessed on 4 February 2021). [CrossRef]

28. Koshere, L. 2(a) (ii)-Designated National Wild and Scenic Rivers: The Confluence of Local Management and Federal Protection. Georg. Wright Forum 2008, 25, 45-51.

29. Ohio Environmental Protection Agency. Total Maximum Daily Loads for the Upper Little Miami River Final Report. $2002 ;$ p. 92. Available online: https:/ / epa.ohio.gov/portals/35/tmdl/ULMR_finalreport.pdf (accessed on 4 February 2021).

30. Department of Interior. The Little Miami River a Wild and Scenic River Study; Bureau of Outdoor Recreation. 1973 ; p. 128. Available online: https: / www.rivers.gov/documents/plans/little-miami-plan.pdf (accessed on 4 February 2021).

31. Hanson, K. The Wild and Scenic St. Croix Riverway. Georg. Wright Forum 2008, 25, 27-36.

32. Interagency Wild and Scenic Rivers Coordinating Council. Wild and Scenic Rivers and the Use of Eminent Domain. 1998; p. 20. Available online: https:/ / www.rivers.gov/documents / eminent-domain.pdf (accessed on 4 February 2021).

33. Janson, D. Tocks Dam: Story of 13-Year Failure. The New York Times. 4 August 1975, p. 45. Available online: https://www.nytimes. com/1975/08/04/archives/tocks-dam-story-of-13year-failure.html (accessed on 4 February 2021).

34. Becker, P. Reflections on Upper Delaware: Crafting controls. In Tri-County Independent; Honesdale, P.A., Ed.; 2019; Available online: https: / /www.tricountyindependent.com/news/20190509/reflections-on-upper-delaware-crafting-controls (accessed on 4 February 2021).

35. NPS. 30th Anniversary; Upper Delaware Scenic and Recreational River. 2015. Available online: https://www.nps.gov/upde/ planyourvisit/anniversary.htm (accessed on 4 February 2021).

36. NPS. Partnership Wild and Scenic Rivers. 2019. Available online: https://www.nps.gov/orgs/1912/partnership-wild-andscenic-rivers.htm (accessed on 4 February 2021).

37. NPS. Partnership Wild \& Scenic Rivers 20 Years of Success Protecting Nationally Significant River Resources through Locally Based Partnerships. p. 28. Available online: https://www.nps.gov/orgs/1912/upload/PWSRforweb_508.pdf (accessed on 4 February 2021).

38. Ray, C. Endogenous socio-economic development in the European Union-Issues of evaluation. J. Rural Stud. 2000, 16, 447-458. [CrossRef]

39. Ray, C. The EU LEADER Programme: Rural Development Laboratory. Sociol. Rural. 2002, 40, 163-171. [CrossRef]

40. European Commission. Fact Sheet: The LEADER Approach. 2006, p. 28. Available online: http://old.europe.bg/upload/docs/ leader.pdf (accessed on 4 February 2021).

41. Shucksmith, M. Endogenous Development, Social Capital and Social Inclusion: Perspectives from leader in the UK. Sociol. Rural. 2002, 40, 208-218. [CrossRef]

42. Ray, C. Culture Economies: A Perspective on Local Rural Development in Europe; Centre for Rural Economy: Newcastle, UK, 2001; p. 155. Available online: https://www.ncl.ac.uk/media/wwwnclacuk/centreforruraleconomy/files/culture-economy.pdf (accessed on 4 February 2021).

43. Gkartzios, M.; Lowe, P. Revisiting Neo-Endogenous Rural Development. In The Routledge Companion to Rural Planning; Scott, M., Gallent, N., Gkartzios, M., Eds.; Routledge: New York, NY, USA, 2019; pp. 159-169.

44. Lowe, P.; Phillipson, J.; Proctor, A.; Gkartzios, M. Expertise in rural development: A conceptual and empirical analysis. World Dev. 2018, 116, 28-37. [CrossRef]

45. Yin, D.K. Case Study Research: Design and Methods, 3rd ed.; SAGE: London, UK, 2003; p. 181.

46. Charmaz, K.C. Constructing Grounded Theory: A Practical Guide through Qualitative Analysis, 1st ed.; SAGE: London, UK, 2006; p. 208.

47. Yin, D.K. Case Study Research: Design and Methods, 2nd ed.; SAGE: London, UK, 1994. 
48. Miller, J.; Hunt, A.R.; Roberts-Lawler, N.; Reeves, C.; Wu, M. Social Dimensions of River Restoration: Searching for the Missing Connections. Forthcoming 2021.

49. Wu, M.; Hsu, T.D.; Rossi, A.; Roberts-Lawler, N.; Hunt, A.R. Revisiting the Musconetcong after 10 Years. 2021, forthcoming.

50. Hsu, T.D.; Wu, M.; Rossi, A.; Lee, H.L.; Roberts-Lawler, N. Microbial Source Tracking and Bacteria Results on the Musconetcong River.

51. Hsu, T.D.; Yu, D.; Wu, M. Spatial Relationships of E. Coli and Land Use Land Cover on the Musconetcong River. 2021, forthcoming.

52. Field-Juma, A.; Roberts-Lawler, N. Using Community Science to Protect Partnership Wild and Scenic Rivers in the Eastern United States. Sustainability 2021, 13, 2102. [CrossRef]

53. MAC. Musconetcong River National Wild and Scenic Rivers Study Final Study Report; MAC: Washington, DC, USA, $2004 ;$ p. 123.

54. MRMC. Minutes of the 21 October 2008 Meeting; Bethlehem Township Administrative Annex: West Portal, NJ, USA, 2008.

55. MRMC. Minutes of the 16 December 2008 Meeting; Heritage Conservancy: Port Murray, NJ, USA, 2008.

56. MRMC. Minutes of the February 17 Meeting; Heritage Conservancy: Port Murray, NJ, USA, 2009.

57. MRMC. Meeting Minutes 20 October 2009; MWA River Resource Center: Asbury, NJ, USA, 2009.

58. MRMC. Meeting Minutes 20 April 2010; MWA River Resource Center: Asbury, NJ, USA, 2010.

59. MWA. Our Mission \& History; 2020. Available online: https://www.musconetcong.org/mission-history (accessed on 4 February 2021).

60. Musconetcong Wild and Scenic Rivers Act. Public Law 109-452. Enacted 22 December 2006. Codified at 16 U.S.C. 1271.

61. Pohatcong Township. Resolution of the Township of Pohatcong County of Warren in Support of the Wild and Scenic Designation of the Musconetcong River; Pohatcong Township, NJ, USA, 2018.

62. NPS. Letter from Reginald Chapple, Acting Assistant Director, Partnerships and Civic Engagement to Musconetcong River Management Council L15 (2240); NPS: Washington, DC, USA, 2020.

63. NJDEP. 2003-2007 New Jersey Statewide Comprehensive Outdoor Recreation Plan. 2003, p. 133. Available online: https:/ www. njleg.state.nj.us/OPI/Reports_to_the_Legislature/outdoor_recreation_plan_2003_2007.pdf (accessed on 4 February 2021).

64. NJDEP. 2005-2007 Land Preservation Plan Green Acres Program State Land Acquisition Program. 2005, p. 106. Available online: https:/ / rucore.libraries.rutgers.edu/rutgers-lib/17749/PDF/1/ (accessed on 4 February 2021).

65. NJDEP. 2008-2012 New Jersey Statewide Comprehensive Outdoor Recreation Plan. 2007; p. 147. Available online: https: / / www.nj.gov/dep/greenacres/pdf/scorp_2008.pdf (accessed on 4 February 2021).

66. NPS. Cooperative Agreement P18AC01066 between the United States Department of Interior National Park Service and the Musconetcong Watershed Association; NPS: Philadelphia, PA, USA, 2018; p. 30.

67. NJDEP. American Shad Return to Musconetcong River in Hunterdon and Warren Counties after More Than a Century. 2017. Available online: https:/ / www.nj.gov/dep/newsrel/2017/17_0065.htm (accessed on 4 February 2021).

68. USFWS. Press Release Secretary Jewell Tours Hughesville Dam Removal on Musconetcong River Project Will Improve Fish Passage and Reduce Flooding Risks. 8 September 2016. Available online: https: / www.fws.gov/news/ShowNews.cfm?ref= secretary-jewell-tours-hughesville-dam-removal-on-musconetcong-river-\&_ID=35786 (accessed on 2 February 2021).

69. NJDEP. New Jersey 1996 State Water Quality Inventory Report. 1996, p. 307. Available online: https://rucore.libraries.rutgers. edu/rutgers-lib/34362/PDF/1/play/ (accessed on 4 February 2021).

70. NJDEP. Identification and Setting of Priorities for Section 303(d) Water Quality Limited Waters in New Jersey. 1998 , p. 137. Available online: https:/ / rucore.libraries.rutgers.edu/rutgers-lib/29412/PDF/1/play/ (accessed on 4 February 2021).

71. NJDEP. 2000 New Jersey Water Quality Inventory Report. 2001, p. 306. Available online: https://rucore.libraries.rutgers.edu/ rutgers-lib/37514/PDF/1/play/ (accessed on 4 February 2021).

72. NJDEP. State of New Jersey's Integrated List of Waterbodies. 2002, p. 87. Available online: https://www.state.nj.us/dep/wms/ bears/docs/2002_Final_Integrated_List.pdf (accessed on 4 February 2021).

73. RCE. Watershed Restoration and Protection Plan for the Musconetcong River Watershed from Hampton to Bloomsbury Water Quality Monitoring Data Report; Water Resources Program: New Brunswick, NJ, USA, 2011; p. 196.

74. Rossi, A.; Wolde, B.T.; Lee, L.H.; Wu, M. Prediction of recreational water safety using Escherichia coli as an indicator: Case study of the Passaic and Pompton rivers, New Jersey. Sci. Total Environ. 2020, 714, 136814. [CrossRef]

75. NJRCD. Musconetcong River Watershed Protection Plan: Hampton to Bloomsbury; NJRCD: Asbury, NJ, USA, $2012 ;$ p. 178.

76. William Penn Foundation. Delaware River Watershed Initiative. 2020. Available online: https://williampennfoundation.org/ delaware-river-watershed-initiative (accessed on 4 February 2021).

77. Wilson, E.; Bromer, C.; LaRoche, D. Balancing the Competing Demands of Strategic Philanthropy: The Case of the Delaware River Watershed Initiative. Found. Rev. 2019, 11, 84-98. [CrossRef]

78. Hsu, T.D.; David Lee, L.H.; Rossi, A.; Yussof, A.; Lawler, N.; Wu, M.Y. Evaluating Microbial Water Quality and Potential Sources of Fecal Contamination in the Musconetcong River Watershed in New Jersey, USA. Adv. Microbiol. 2019, 9, 385-397. [CrossRef]

79. Molfetta, K. Governance of Federally Protected Rivers: An Institutional Analysis of the Partnership Approach to Wild and Scenic River Management in the White Clay Creek. Master's Thesis, University of Delaware, Newark, DE, USA, 2016; p. 202. Available online: https://udspace.udel.edu/bitstream/handle/19716/20331/2016_MolfettaKristen_MS.pdf?sequence=1 (accessed on 4 February 2021). 